\title{
The Prospect of Physiological Events Associated with the Micropropagation of Eucalyptus sp.
}

\author{
Rambod Abiri ${ }^{1, *}$, Narges Atabaki ${ }^{2}$, Hazandy Abdul-Hamid ${ }^{3, *}$, Ruzana Sanusi ${ }^{1,3}$, \\ Nor Aini Ab Shukor ${ }^{1,3}$, Noor Azmi Shaharuddin ${ }^{2,4}$, Siti Aqlima Ahmad ${ }^{2} \mathbb{D}$ and Sonia Malik 5 \\ 1 Department of Forestry Science and Biodiversity, Faculty of Forestry and Environment, \\ Universiti Putra Malaysia, UPM Serdang 43400, Selangor, Malaysia; ruzanasanusi@upm.edu.my (R.S.); \\ dnoraini@upm.edu.my (N.A.A.S.) \\ 2 Department of Biochemistry, Faculty of Biotechnology and Biomolecular Sciences, Universiti Putra Malaysia, \\ UPM Serdang 43400, Selangor, Malaysia; atabaki.narges@gmail.com (N.A.); \\ noorazmi@upm.edu.my (N.A.S.); aqlima@upm.edu.my (S.A.A.) \\ 3 Laboratory of Bioresource Management, Institute of Tropical Forestry and Forest Products (INTROP), \\ Universiti Putra Malaysia, UPM Serdang 43400, Selangor, Malaysia \\ 4 Institute of Plantation Studies, Universiti Putra Malaysia, UPM Serdang 43400, Selangor, Malaysia \\ 5 Health Sciences Graduate Program, Biological \& Health Sciences Centre, Federal University of Maranhão, \\ São Luís 65085-580, MA, Brazil; 777soniamalik@gmail.com \\ * Correspondence: rambod.abiri@gmail.com (R.A.); hazandy@upm.edu.my (H.A.-H.)
}

Received: 14 September 2020; Accepted: 23 October 2020; Published: 18 November 2020

\begin{abstract}
Micropropagation is a reliable technique in biotechnology and genetic engineering domain, which has been widely applied for rapid mass propagation of plants in vitro condition. Through micropropagation techniques, reproduction of plants can be attained from different explants using organogenesis and somatic embryogenesis. Over the decades, micropropagation techniques have offered tremendous potential for forest tree improvement. Eucalyptus is a woody plant species recalcitrant to in vitro culture. In general, the micropropagation of Eucalyptus culture processes and the genotype, environment surroundings, and age of explants in culture media is frequently linked with the occurrence of micropropagation variation. In the current review paper, an update of the most important physiological and molecular phenomena aspects of Eucalyptus micropropagation was linked to the most profound information. To achieve the mentioned target, the effect of plant growth regulators (PGRs), nutrients, other adjuvant and environmental features, as well as genetic interaction with morpho- and physiological mechanisms was studied from the induction to plant acclimatisation. On the other hand, important mechanisms behind the organogenesis and somatic embryogenesis of Eucalyptus are discussed. The information of current review paper will help researchers in choosing the optimum condition based on the scenario behind the tissue culture technique of Eucalyptus. However, more studies are required to identify and overcome some of the crucial bottlenecks in this economically important forest species to establish efficient micropropagation protocol at the industrial level.
\end{abstract}

Keywords: Eucalyptus; somatic embryogenesis; organogenesis; myrtaceae; micropropagation; regeneration; plant acclimatization

\section{Introduction}

Eucalyptus (family Myrtaceae) is a large genus of fast-growing evergreen trees and ornamental shrubs with more than 900 species, native to Australia, Indonesia, India, Portugal, South Africa, Brazil, Chile, and France [1]. The economic importance and commercial value of Eucalyptus have long been 
considered in many parts of the world due to its hard timber, resistance to biotic stresses, rapid growth, and high profitability [2-4].

Furthermore, increasing global demand for timber, pulp, and paper products has significantly changed the plantation culture of Eucalyptus species all over the world [5]. Besides having extensive use of Eucalyptus in agroforestry systems, the essential oils extracted from this tree have been widely used in modern ethno-pharmaceutical studies due to its various biological activities and medicinal properties [6]. To date, natural and cultivated Eucalyptus forests have been considered as the initial genetic resources for agroforestry plans and tree breeding programs [7]. Despite the abundance of natural Eucalyptus forests, cultivation of Eucalyptus by seed is the most traditional way of propagation with varying degrees of competitive success and establishment. In the latter stage, vegetative propagations methods have also been applied for Eucalyptus improvement programs [8,9]. Vegetative progeny methods are broadly being used for asexual propagation of forest trees. The primary vegetative propagation techniques are grafting, layering, root cuttings, and rooting of the shoot. Generally, the effectiveness of the methods depends on the physiological structure, shape, performance, and age of the donor tree [10]. Over recent decades, conventional breeding tools which have been implemented in forestry improvement programs become the main strategy to multiply forest trees [11]. However, the bottlenecks of conventional breeding techniques opened a new window to the clonal propagation of Eucalyptus.

Clonal propagation is often considered as one of the most critical in vitro platforms to increase multiplication rate of Eucalyptus sp. in forestry breeding programs and biotechnology research [12]. Micropropagation, which mainly achieved via somatic embryogenesis and organogenesis, is the true-to-type, virus-free, and rapid propagation technique [13]. The in vitro culture of Eucalyptus depends on several factors including external aspects (sugar concentrations, $\mathrm{pH}$, media composition, plant growth regulators (PGRs), luminosity, and temperature) and internal features (physiological conditions, age, and genotype) [13]. Despite the advancement in the micropropagation method, the obstacles in callus induction, regeneration, root induction, and acclimatisation are still the major challenges for clonal propagation of Eucalyptus. On the other hand, hyperhydricity, rapid browning, and poor explant response, which cause poor growth of explants and even failure of tissue culture procedure, are some of the other major factors affecting in vitro propagation of Eucalyptus [14]. The advantages and disadvantages of micropropagation methods in plants are presented in Figure 1 [15].

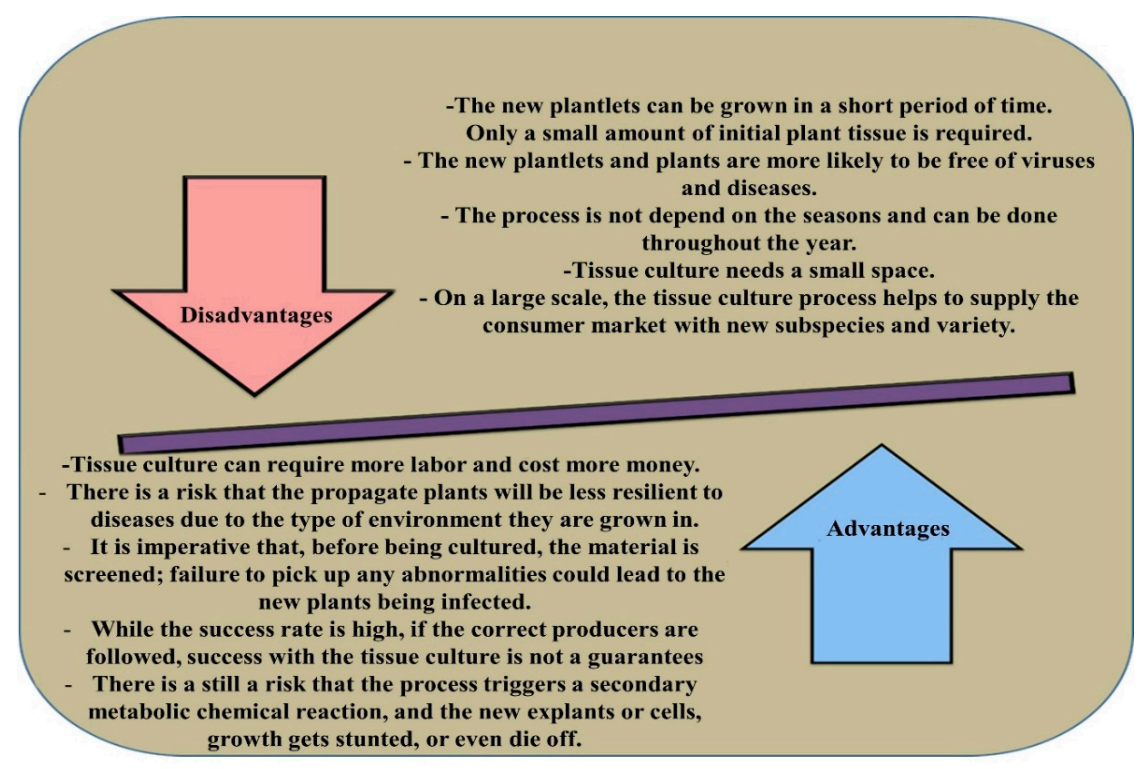

Figure 1. The advantages and disadvantages of micropropagation in plants.

To date, several micropropagation techniques and in vitro protocols have been developed for tissue culture of Eucalyptus. Regardless of the advances, micropropagation of Eucalyptus has been 
met with limited success (failures) and applicability. This is due to the lack of studies focused on the mechanisms, strategies, and interactions of internal and external factors under in vitro conditions. Keeping this in view, this current review aims to clarify the rationale mechanisms behind the observed phenomenon in Eucalyptus tissue culture. Furthermore, this is an extensive review of some intriguing aspects of internal mechanisms of Eucalyptus in response to external (physico-chemical) factors under in vitro conditions.

\section{General Features of Micropropagation and Their Applications in Eucalyptus}

Organogenesis and somatic embryogenesis are the two substitute pathways in plant micropropagation [16]. However, some literature emphasised the shoot proliferation as a separate class of Eucalyptus micropropagation method. To better understand the prospects of in vitro scenarios, in the coming section, we briefly describe the concepts of organogenesis and somatic embryogenesis in Eucalyptus (Figure 2).

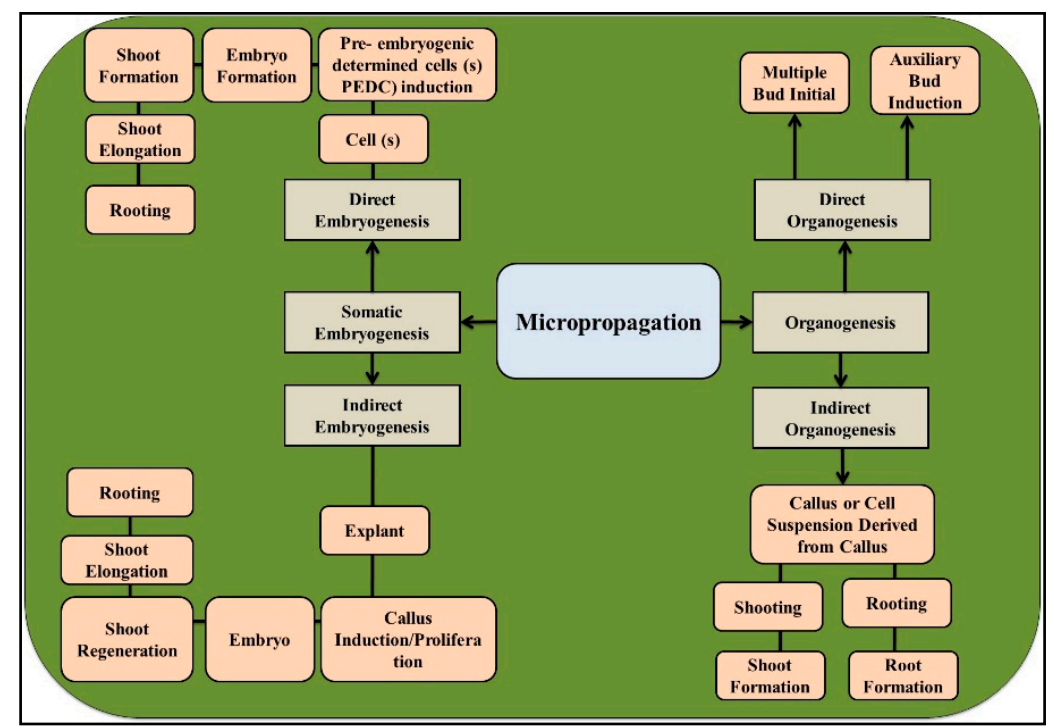

Figure 2. Schematic graph of different regeneration methods applied in micropropagation techniques in plants. Micropropagation is divided into two mainstream groups, namely, organogenesis and somatic embryogenesis (SE). Each class is also classified into direct and indirect methods. The general pattern of direct embryogenesis starts from tissue (s) or cell (s) in the lack of callus proliferation, through pre-embryogeneic determined cells (PEDCs). PEDCs are those types of plant cells that have the capability of embryonic development and need optimum condition (s) as well as PGRs to for embryogenesis. In the second type of SE, which is indirect embryogenesis, embryos are formed and developed after callus proliferation by using PGRs. Similarly, organogenesis is divided into direct and indirect pathways. In direct route, the plant is manipulated through the initiation of explants on culture media. Indirect organogenesis is achieved via manipulation of plants through callus induction and organ formation.

\subsection{Organogenesis}

Organogenesis is the vegetative propagation by which plant organs such as flower buds, shoots, and roots are produced from the cells and tissues (the unusual points of origin) under in vitro conditions. The type of organogenesis (direct and indirect) depends on the presence of relative concentrations of hormones and explants in the culture medium [17]. Indirect organogenesis is the formation and development of organs from an amorphous tissue, callus, or cell suspension. Additionally, this propagation method is a reliable technique, which has been applied for the production of genetically modified plants from calli [18]. On the other hand, development of new organs from the explants (axillary buds), which forms new shoots and buds, is known as direct organogenesis [19]. 
In Eucalyptus, the composition of different factors such as carbon, various vitamins, amino acids, gelling agent, macro- and micronutrients, and other additives has affected the efficacy of both types of organogenesis [20]. For instance, during indirect organogenesis of Eucalyptus camaldulensis hybrids, the combination of naphthyl acetic acid (NAA) and 6-benzylaminopurine (BAP) showed a better efficacy as compared to the application of zeatin, kinetin, casein hydrolysate, and 2,4-Dichlorophenoxyacetic acid (2,4-D) [21]. Additionally, callus induction was observed in E. camaldulensis hybrids cultivated on Murashige and Skoog Basal (MS) media added with $1 \mathrm{mg} \mathrm{L}^{-1} \mathrm{NAA}$, and the highest rate of somatic embryogenesis was achieved on MS basal medium fortified with $0.1 \mathrm{mg} \mathrm{l}^{-1} \mathrm{NAA}$ and $0.5 \mathrm{mg} \mathrm{l}^{-1}$ benzyladenine (BA) [22].

\subsection{Somatic Embryogenesis}

Somatic embryogenesis (SE) is a multifactorial, non-sexual, and complex biotechnological tool. This artificial method produces bipolar embryos through physiological, biochemical, and molecular pathways from somatic tissues. During SE, somatic cells of plants become totipotent and alter their pathway of development, resulting in the formation of a complete plant from somatic embryos [23]. In plants, two arrays of the somatic embryos have been reported including indirect somatic embryogenesis induced from an unorganised calli and direct somatic embryogenesis induced from the pre-embryogenic cells (cells of the nucellus) [24]. Indirect embryogenesis needs redetermination of differentiated cells process, callus induction, proliferation, and the development of the embryogenically determined phase [25]. Generally, the effects of suitable PGRs at specific concentrations play an integral role in the re-entry of cells into mitosis and determination of the embryogenic phase [26]. Nonetheless, during direct somatic embryogenesis, which is a rare type of $\mathrm{SE}$, the cell(s) produces embryos without the formation of an intervening callus. To achieve direct embryogenesis, pre-embryogenic determined cells (PEDC) require favourable conditions and specific type of PGRs to enter mitosis and complete embryogenesis [27].

Over the decades, numerous somatic embryogenesis protocols for several Eucalyptus species have been reported $[13,28,29]$. However, the occurrence of somaclonal variation, low percentage of embryogenic initiation, and an inability of somatic embryos to reach complete maturation limit somatic embryogenesis adoption for clonal propagation in Eucalyptus [14]. It has been also reported that several factors, such as hormonal type and level, culture media, and ontogenetic age of tissue interfere with the diverse phases of somatic embryos [30]. Nonetheless, there is a notorious paucity of studies addressing ultrastructural, histological, and cytological evidence on the diverse features linked to the frequency induction and proliferation of somatic embryos. Despite the morphological resemblances of somatic embryos with zygotic ones at the proliferation and developmental phases, a lack of clear definition has been stated in some other phases of proliferation and developmental steps in Eucalyptus [31]. For example, histological and morphological investigations on the embryogenic cell of Eucalyptus globulus, Eucalyptus grandis, and Eucalyptus nitens at diverse development phases demonstrated the usual features of other somatic embryogenic structures including small vacuole, prominent nucleus, small volume, and dense cytoplasm [32].

The success rate of a propagation technique in Eucalyptus depends on both quality (genetic stability and growth rate) and quantity (survival) of the regenerated plants. The combination of above-mentioned factors associated with the genotypes of Eucalyptus is the most effective aspect in both somatic embryogenesis and organogenesis. In the following sections, the effects of most important factors on both somatic embryogenesis and organogenesis of Eucalyptus are discussed.

\section{Importance of Eucalyptus Root Architecture and Behaviour}

Root growth is a critical parameter during the vegetative propagation of Eucalyptus species, which is mainly divided into three categories viz., root induction, root formation, and root elongation. Root induction is characterised by the biochemical and molecular events preceding any noticeable morphological/histological modifications changes. Root formation is a cell division phase, 
which involves the radical primordia establishment and root meristem organisation. Root elongation is the result of an enlargement of new cells formed by the constant cell divisions in the meristematic cells of root. Difficulty in rooting is one of the major obstacles to achieve successful micropropagation, and therefore, it is the most challenging phase during tree generation in vitro condition [33]. Therefore, increases in root number, length, and quality are the most important targets during rooting phase in planting programme and in vitro manipulations of woody plants [34]. Although propagation of woody plants such as various Eucalyptus clones by micro-, mini-, and macro- cutting has been thriving over the decades, the micropropagation technique has enhanced higher plantlet multiplication rates [12]. This technique, most probably, should be the only effective biotechnological method of producing some difficult-to-root clones [35]. Implementing the outcomes of analysis on micropropagation of Eucalyptus, such as other plants, demonstrated that post-acclimatisation and graviperception architecture are controlled by the exogenous auxin analogue, added in the pre-rooting culture media [12,36]. It has been suggested that clones obtained from in vitro propagated plants have a better root structure, growth, and morphology as compared to ex vitro grown Eucalyptus trees [37].

The root system comprises three different morpho- and physiological states including primary, lateral, and adventitious roots [38]. The primary root which is the main, largest, and central axis (taproot) of a root system is basically formed during the embryogenesis phase and will extend after germination. Lateral roots (LRs) are often initiated from roots, whereas adventitious roots are always developed from leaf-derived or stem cells [38]. Lateral roots usually arise from existing ones, whereas adventitious roots form artificially (application of phytohormone or wounding) or naturally, and (changes in environmental conditions) from stem or leaf tissues [38]. Adventitious root (AR) development in Eucalyptus is a complex and multifactorial procedure influenced by the plant age, stress conditions, environmental factors, genetic traits, mineral nutrition, and phytohormones [39,40]. AR is derived from different tissues and cells of Eucalyptus, including hypocotyl pericycle, vascular parenchyma, young secondary phloem, and interfascicular cambium. Adventitious root induction is stated by biochemical and molecular changes, such as accumulation of high auxin dosage at the wound area or formation of an active sink for carbohydrates. The appearance of cell divisions is the first step in AR initiation, and its expression involves the root primordia growth and development through the stem tissues and formation of vascular connections [39]. Anatomically, AR development initiates with the induction phase in Eucalyptus, which involves the somatic reprograming of preferred target cells to new meristematic cells in the lack of any mitosis leading to the formation of internal root meristems. Continuously, the induction phase of AR is completed by the formation of dome-shaped root primordia, establishment of vascular connections, and emergence of root [41]. The position of root initials in stem cuttings of Eucalyptus is species-specific, and during micropropagation, shoots locate from the procambium, from newly-formed xylem, or from old vascular tissue [12,42]. The adventitious rooting competence is heritable and quantifiable [12]. Based on the genetic predisposition of Eucalyptus species, their clones are categorised into two main groups, namely, easy- or difficult-to-root. To date, different quantitative trait loci (QTLs) have been identified as associated with adventitious rooting, the percentage of rooted cuttings, with a large phenotypic variation arising from Eucalyptus tereticornis, E. globulus, Eucalyptus urophylla, and Eucalyptus grandis $\times$ Eucalyptus urophylla [42].

\section{The Relationship between Root Structure and Shoot System in Eucalyptus}

In Eucalyptus, the root structure, growth, and function are controlled by root-to-shoot signalling through nutrient movement via root-sourced xylem as well as leaf-sourced phloem. For instance, cytokinins are produced primarily in root tips or meristems and transported to shoots via the xylem where they control the cell division process and the rate of leaf senescence in mature plants [43]. On the contrary, the auxins are synthesised in shoot tips like young leaves and leaf primordial, and actively transported to the root zone from the shoot system via the vascular structure [44]. The auxin regulates growth response mechanisms of root tips response to gravity [45]. A decreasing trend in root growth and auxin production has been reported when plants were decapitated; however, application of auxin 
to the decapitated shoot tip [46], or in vitro conditions reversed the damages caused to plants [47]. Eucalyptus shoots were found to produce roots through multiplication and elongation stages upon supplementation of auxin to the medium. Nonetheless, when auxin was absent from the multiplication stage and limited in elongation period, rooting on the auxin-free medium was significantly reduced [44]. The above reports suggest the positive interactions between root formations and shoot growth [43].

The dynamic relationships between shoots and roots demonstrated that each organ needs to act synergistically in order to have a successful tissue culture system in Eucalyptus [35]. Studies on different morpho- and physiological features of two methods of cultivation (seedling and cutting) in E. globulus showed similar shoot/root ratio, growth rate, and plant height. However, the larger root system caused more resistance to uprooting in seed-derived E. grandis $\mathrm{x}$ E. nitens, when compared to field-grown micropropagated trees [37]. Root/shoot ratio, on the other hand, is a reliable indicator, which shows adaptations to atmospheric and soil water deficits and vulnerability to transplanting both Eucalyptus hypochlamydea and Eucalyptus dumosa [48]. Additionally, comparison of shoot height with hardwood seedling root volume has been applied to measure subsequent tree dimensions and growth rates [49]. While root/shoot mass ratios are a good indicator of the plant's investment in their root structures at any point of time through the plant's basic biomass allocation, it cannot be used for the total investment made by plants in their root systems (due to flux of assimilates in the system) [50].

\section{Role of Plant Growth Regulators (PGRs) in Micropropagation of Eucalyptus}

Although several factors directly and indirectly influence the micropropagation of Eucalyptus, the addition of different dosages of PGRs especially auxins into the media is one of the most important factors influencing the gain of cellular competence, triggering embryogenic re-differentiation, dedifferentiation, and organ(s) formation [51]. It is pertinent to mention here that prolonged exposure of the plantlets to auxins could negatively impact the morphological and physiological features of in vitro propagated plants including somaclonal variation, structure distortion, fasciation, dwarfism, and hyperhydricity [52]. Therefore, determining the optimum auxin concentration to induce somatic embryogenesis and organogenesis is a critical step, especially in recalcitrant species such as Eucalyptus.

\subsection{Role of Auxins on Root Structure and Formation}

The regulatory functions of auxins have been reported at the cellular mechanisms such as cell division, growth, and differentiation in Eucalyptus, and this PGR family can stimulate lateral or isodiametric expansion or axial elongation [53]. The functions of auxin and its polar auxin transport (PAT) have been reported in several physiological and genetic regulation mechanisms of root development and adventitious root induction such as root cell patterning, maintenance, and regulation of the root zonation and meristem [54]. Auxins are also laterally accumulated in the root cap (RC) zones as the primary signal triggering gravisensitivity and gravitropic bending [55].

Indole-3-acetic acid (IAA; natural auxin) is the most common auxin produced by plants and microorganisms via tryptophan-independent or tryptophan-dependent mechanism. Although an indole amino acid tryptophan (Trp) is the main mechanism of auxin biosynthesis, Trp-independent pathways have also been reported as alternative mechanisms in plants [56]. The biosynthesis of IAA via Trp and indole-3-pyruvic acid (IPA) is transaminated (by tryptophan transaminase) to IPA, which is decarboxylated to indole-3- acetaldehyde (IAAld) [57]. The IAA formation occurs either through dehydrogenation or oxidation of IAAld. Trp-dependent pathways for IAA are the indole-3-acetamide (IAM), indole-3-acetaldoxine (IAOx), and tryptamine pathways [58]. Indole-3-butyric acid (IBA) biosynthesis is analogous to IAA. The mentioned biosynthesis of IBA occurs through a longer side chain of Trp mechanism, via $\beta$-oxidation in chain-elongation reactions, similar to biosynthesis of fatty acid. Similarly, IBA is also formed via Trp-independent pathways as mentioned for IAA [59]. As plants use auxins for several developmental phases, there are numerous advantages to store auxin. In this regard, IAA can be stored in either conjugated form or as IBA, which allows the availability of free IAA, either through $\beta$-oxidation to convert IBA to IAA or through hydrolysis to free the conjugated 
form [56]. Reportedly, IBA conjugation products was shown to be a better source of free IAA than those of IAA [60]. Both IAA and IBA are quickly conjugated and metabolised within Eucalyptus tissues. Auxin-conjugates perform an important function in auxin metabolism and physiology by enabling utilisation, storage protecting them from enzymatic deactivation, and in maintaining a homeostatic concentration of hormone in plant [61]. No oxidation products have been reported for IBA conjugates. Thus, IBA remains at elevated levels longer than IAA [61].

The concentration of this well-known auxin is fluctuated during different phases of root development and adventitious root induction. For example, at root induction stage, the level of IAA is increased and then dropped significantly during the root formation phase. The IAA level shot up again in the root elongation stage [62]. Regardless of the presence or absence of other auxin, IAA is considered to be an integral phytohormone in the rooting phase [44]. IAA is transported basipetally, through membrane-bound transport proteins of the AUX 1, PIN-FORMED (PIN), and P-GLYCOPROTEIN (PGP) families, or diffusion, which provides auxin efflux and influx occurring mainly through the phloem [31]. In Eucalyptus clones, supplementing auxin analogue in the pre-rooting micropropagation media caused graviperception. Considering this fact, IAA, as an essential hormone, could not be substituted by its analogues IBA or NAA [47]. As auxin is able to retard root elongation and stimulates cell growth under in situ conditions, IBA serves as a source of IAA in Eucalyptus clones [56,63]. Auxin cooperates antagonistically or synergistically with other PGRs such as strigolactones (SL), polyamines (PA), brassinosteroids (BR), jasmonic acid (JA), abscisic acid (ABA), gibberellins (GA), ethylene, and cytokinins (CK), controlling root morphogenesis and elongation by integrating their signals in transport and distribution of auxin biosynthesis (Figure 3).

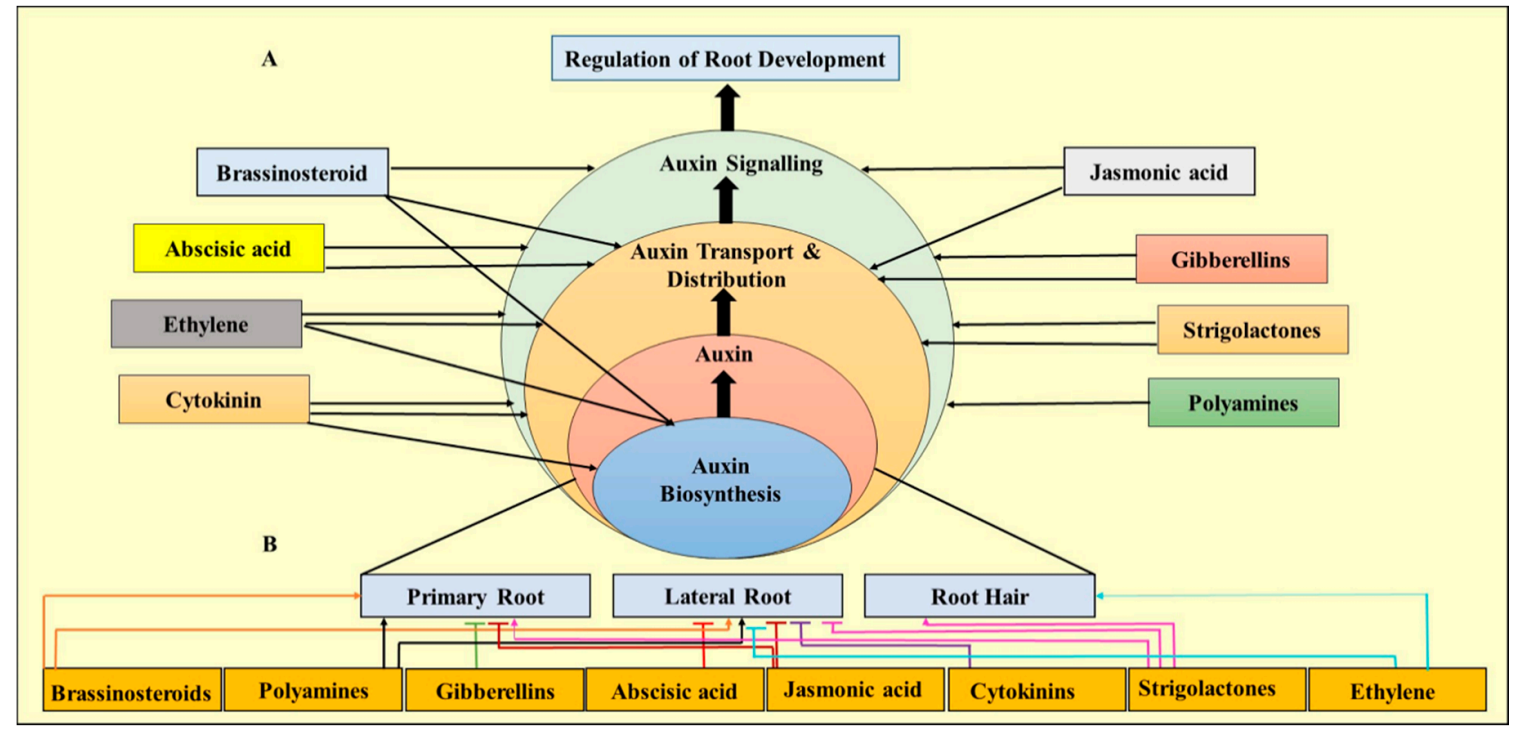

Figure 3. The schematic graph of phytohormone signalling in root development. For root growth and development, auxin is moved from cell to cell by appropriate auxin influx and efflux transporters, such as p-glycoproteins (PGPs), pin formed (PIN), and like-aux1 (LAX) proteins. (A) antagonistic or synergistic activities of auxins with other plant growth regulators, and (B) controlling root morphogenesis and elongation by integrating the hormonal signals in transport and distribution of auxin biosynthesis.

Reportedly, high concentration of auxin is vital for adventitious root (AR), before the establishment of root meristemoid. As mentioned earlier, low concentration of auxin leads to root elongation through inhibition of lateral root development [64]. In Arabidopsis, for example, IAA is synthesised from tryptophan by using flavin-containing monooxygenases (YUCCA) and TRYPTOPHAN AMINOTRANSFERASE OF ARABIDOPSIS (TAA). In this pathway, indole-3-pyruvate (IPA) is first produced from tryptophan by TAA, and in the next step, IAA is produced from IPA by applying YUC [65]. 
On the other hand, the combination of kinetin and IBA dramatically decreases the average root diameter and leads to the highest percentage of callus induction. Reportedly, $\rho$-chlorophenoxyisobutyric acid is able to inhibit transduction signals of auxins. Kinetin considerably reduces mean root quantity and rooting percentage and produces callus formation $[66,67]$. Auxins are responsible for the foundation of apical meristem. Additionally, auxins and downstream transcriptional regulation modify the cell wall to make exact morphogenetic changes [68]. Furthermore, cross-talk of auxin with other hormonal signalling pathways such as cytokinins is critical for accurate organ initiation [21,69]. Based on the overall pattern of adventitious root induction from stem cuttings of trees and woody plants, roots are induced from the secondary phloem but may also arise from the vascular-phloem and -cambium [66]. Nonetheless, sometimes vascular cambium or meristematic pro-cambium, and either old or newly vascular tissues, shaped xylem [70].

The addition of an antagonist or auxin inhibitors after root formation showed the exact need of the verified clone for IAA to proceed with normal root physiology and development $[5,69]$. The presence of either the IAA-specific transport inhibitor 2,3,5-triiodobenzoic acid (TIBA) or the auxin antagonist kinetin caused the loss of root gravity perception, which is a response not detected in the shoots treated by p-chlorophenoxyisobutyric acid (PCIB). Moreover, PCIB and kinetin treatments demonstrated significantly smaller mean root diameters than in control, but the treatment with TIBA showed the opposite impact [47]. All the above demonstrated changes in horizontal root architecture and the loss in gravity perception happened not due to a loss in auxin signal transduction but to a disruption in IAA efflux [37,47,48]. Reportedly, a disruption in the efflux of auxin promotes either the through auxin regulation via a cytokinin or through auxin transport inhibition [71,72]. This phenomenone is interfered with root cap development and gravitropism, which respond to regulate auxin transport and specific supply with respect to minimum and maximum auxin concentrations [71,73,74]. Regardless of the presence of auxin analogue, supplementing media with TIBA, PCIB, and kinetin considerably reduced the percentage of rooting formation. Additionally, exogenous IBA, a more effective rhizogenic auxin than IAA, typically caused the highest basal callus induction. This hormone could significantly increase root diameters of Eucalyptus when supplemented in the presence of TIBA, and absence of kinetin [35,75]. The above observation confirmed the inhibitory effect of TIBA hormone for auxin transportation.

Degradation of auxin could occur by peroxidases after cutting severance; however, auxin degradation can be prevented by applying different antioxidants such as flavonoids and phenols at cutting bases [39]. Auxins produced in the shoot tip are basipetally transported to the stem by two transporters, namely, asymmetrically distributed efflux PIN-FORMED (PIN) proteins and auxin influx AUXIN1/LIKEAUX1 (AUX/LAX) [76,77]. Inside the cells, auxin-regulated genes are expressed by selective proteolysis of its repressors AUXIN/INDOLE- 3-ACETIC ACID (Aux/IAA) together with the co-repressor TOPLESS (TPL); which can release AUXIN RESPONSE FACTORS (ARFs) and regulate auxin responsive genes [78]. F-BOX protein TRANSPORT INHIBITOR RESPONSE 1, which is a part of AUXIN SIGNALING F-BOX (AFBs) family, can mediate Aux/IAA degradation [79]. The degradation of Aux/IAA can be mediated by the F-BOX protein TRANSPORT INHIBITOR RESPONSE 1 (TIR1) (an auxin receptor) [6], a member of a gene family that includes AUXIN SIGNALING F-BOX (AFBs). AUXIN BINDING PROTEIN 1 (ABP1), is another putative auxin and extracellular receptor with fast responses, especially non-transcriptional [80]. It has been documented that WUSCHELRELATED HOMEOBOX11 transcription factor (WOX11) is able to mediate AR development in Arabidopsis (model plants) [81].

\subsection{Effect of Ethylene on Root Architecture}

The phytohormone ethylene can interact at the expression step by promoting early induction and late formation of ARs. In contrast, ethylene inhibits the late induction step in Eucalyptus [64]. A number of functions of ethylene have been proposed on AR development, but most of them support that its impacts are associated with the signalling, transport, and synthesis of auxin [82]. Reportedly, high expression level of auxin-responsive genes such as $A R R 1, I A A 12$, and TPL as well as low concentration of auxin in microcuttings are linked with hard-to-root circumstance in Eucalyptus. AR development is reported 
by using exogenous auxin which reduced ARR1 and TPL expression in E. globulus [83]. On the other hand, improved root system of derived microcutting and higher allocation of carbohydrates to their basal portion were observed upon culturing Eucalyptus in sugar free media under far-red light enrichment. At the same time, carbohydrate metabolism-related genes, SUCROSE SYNTHASE 1 (SUS1), STARCH SYNTHASE 3 (SS3), and SUCROSEPROTON SYMPORTER 5 (SUC5) have also been reported [84].

\subsection{Role of Cytokinins in Micropropagation of Eucalyptus}

Cytokinins are able to stimulate shoot multiplication by suppressing the apical dominance [63]. Reports have demonstrated that BA possesses some beneficial effects over the other cytokinins for organogenesis or shoot multiplication [85-87]. Two non-similar structural groups of natural compounds, viz. ureidic and adeninic derivatives, display cytokinin-like activity [88]. Generally, adenine derivatives are naturally occurring adenine-type cytokinins, and all the ureidic derivatives are urea-based synthetic compounds [89]. Various cytokinin receptors, such as HISTIDINE KINASES (HK) and CYTOKININ RESPONSE 1 (CRE1), are triggered by both the classes of cytokinins and implement the similar binding site in Arabidopsis histidine kinase 4 [90].

Substituted phenylurea is a group of systemic herbicides used against general weed. Phenylurea is a type of PGR that is able to display cytokinin-like activity in several plant culture schemes. N-phenyl- $\mathrm{N}^{\prime}$-[6-(2-chlorobenzothiazol)-yl] urea (PBU) has been introduced as a first purified and synthesised phytohormone [91-93]. Reportedly, addition of PBU developed organogenesis in E. urophylla by stimulation of root formation and reduced browning [94,95]). Reports have shown that application of PBU in micropropagation was able to stimulate the formation of adventitious shoots in E. urophylla by blocking the transcription of the rboh1 gene [91]. The presence of adeninic BPA and ureidic PBU caused callus differentiation by regulating ROS metabolism [91,94,95]. During the adventitious rooting phase, direct or indirect interaction of with or without auxin-signaling pathways with a group of diphenyl urea derivatives (MDPUs) has been observed in rooting-competent cuttings [88]. On the other hand, Brunoni et al. [96] showed that 1,3-di(benzo[d] oxazol-6-yl)urea (BDPU), which is a urea derivative, without auxin- or cytokinin-like activity, possibly interacts with auxin distribution mechanisms and auxin-signaling pathways before and after cell divisions creating the adventitious root meristem. It is worth noting that PBU, a urea derivative with cytokinin-like activity, interacts with the auxin-signaling mechanism to influence the formation of adventitious shoots. It has been confirmed that 6-benzyladenine (6-BA) is less active than PBU for inducing callus in Eucalyptus [93]. Additionally, a higher frequency of adventitious bud produced from Eucalyptus callus in the medium supplemented with PBU [97-99]. The proliferation of secondary embryos from primary embryos of Eucalyptus could cause malformated embryos, directing to oxidation, and in severe condition leads to death. As a result, undifferentiated cells that are the sign of totipotency may have appeared. Notwithstanding the primary promotion of somatic embryos and the proliferation of secondary somatic embryos, these formations did not emerge for seedling or/and germination induction. The induction of embryogenic development in a differentiated cell needs complete cellular reprogramming [100]. The competence or recalcitrance to somatic embryogenesis of Eucalyptus depends on the genetic factor [32,101,102]. However, accurate regulation of chromatin modifications in response to developmental and environmental stimuli regulates the precise temporal and spatial gene expression $[53,100,103]$.

Reactive oxygen species (ROS) is a chemical defence mechanism against different stresses $[3,104,105]$. Respiratory burst oxidase homologue ( $(r b o h)$ gene, which is the main sources of ROS formation in plants, encoded membrane-localized NADPH oxidases. Generation of ROS was performed by transferring electrons from cytosolic NADPH/NADH to apoplastic oxygen [106]. It has been well documented that ROS plays an essential role in the complex signalling network of Eucalyptus cells under stress conditions [107]. However, hydrogen peroxide $\left(\mathrm{H}_{2} \mathrm{O}_{2}\right)$, as a main ROS, displays dual function in metabolism of plants $[58,108,109]$. Reportedly, during the callus browning phase, the amount of $\mathrm{H}_{2} \mathrm{O}_{2}$ increases, and this is followed by modifying the concentration and activity of enzymes linked with 
metabolism of ROS metabolism $[107,110]$. On the contrary, a high level of $\mathrm{H}_{2} \mathrm{O}_{2}$ could cause damage to the structure of cell, with various downstream consequences [111-113]. Therefore, steady-state concentration of cellular hydrogen peroxide must be tightly controlled. The above non-enzymatic and enzymatic ROS scavengers co-regulate the ROS steady-state activity and cell concentration of critical factors for plant growth and development. Following the previous step, ascorbate peroxidase (APX), an isoenzyme, which displays a vital function in $\mathrm{H}_{2} \mathrm{O}_{2}$ metabolism in Eucalyptus is able to speed up the formation of $\mathrm{H}_{2} \mathrm{O}$ from $\mathrm{H}_{2} \mathrm{O}_{2}$ with an electron donor (ascorbate) in different organelles such as the peroxisomes, mitochondria, cytosol, and chloroplasts [106,114]. However, APX expression is differentially controlled under normal growth, development, and environmental stresses $[115,116]$. The activity of APX remarkably decreases the level of $\mathrm{H}_{2} \mathrm{O}_{2}$ and showed an important role in the regulation of antioxidant defence mechanisms in higher plants such as Eucalyptus [116].

The results of investigation on the interaction of cytokinin types, APX expression, and rboh in Eucalyptus showed that PBU repressed the expression of rboh gene and induced the expression of APX gene to decrease browning, while BAP revealed the opposite function [94]. Notwithstanding the important role of APX isoforms, the function of peroxisome APX is poorly understood yet. However, the role of peroxisomes is reported in cellular oxidative metabolism because the ROS derived from peroxisomes possibly plays a role as second messengers in the cytosol to control mechanisms of signal transduction pathways [111]. Studies demonstrated that the induction of APX3, a peroxisomal APX enzyme expressed by BAP alone in the calli, was 492.52 times higher than that of 12-old hypocotyl explants. Moreover, this expression rate was much higher than that of the other two types of calli induced by the combination of PBU or BAP alone. The calli induced on media supplemented with IAA $(0.57 \mu \mathrm{M})$, BAP $(0.57 \mu \mathrm{M})$, and PBU $(3.99 \mu \mathrm{M})$ and DMTU $(20 \mu \mathrm{M})$ demonstrated the highest levels of transcription for all nine APX genes, in parallel with the highest activity of APX enzymes. However, it showed that only transcription levels of peroxisome APX increased dramatically (395.67 times higher than hypocotyl explants) among the three APX isoforms. It has been reported that peroxisomal APX3 showed an important function in the ROS metabolism regulation in the differentiation of E. urophylla callus $[91,94]$. APX3 can be tackled as an initial point for the analysis of ROS metabolism and callus differentiation in future studies. Nonetheless, $\mathrm{H}_{2} \mathrm{O}_{2}$ has been exposed to possess several critical functions in signalling and numerous features of plant development [117]. In Eucalyptus, the change in rboh expression level has not been well examined in the pathway of shoot primordium initiation and formation. Huang and Li [94] reported that during callus differentiation of E. urophylla, two different types of changes happened in the transcription levels of six rboh genes. First, a decline occurred in the rboh1 gene transcription levels in the initial three phases; the second change was increasing in the transcription levels of gene in calli shoot primordia. An increase in the transcription activities of rboh4, rboh5, and rboh6 was observed in the calli with the high $\mathrm{H}_{2} \mathrm{O}_{2}$ contents. Nonetheless, increasing $\mathrm{H}_{2} \mathrm{O}_{2}$ at the early phase of callus differentiation caused browning [91,113]. The rboh isoforms noticeably controlled diverse roles in the mechanism of callus differentiation in Eucalyptus. Generally, regulation of oxidative stress by a combination of DMTU, BAP, and PBU resulted in the formation of adventitious shoots in E. urophylla [14,18,94].

Polyamines, a group of organic compounds, possess physiological regulatory roles during mitosis, and have been considered as stress-reducing compounds under in vitro condition $[4,111]$. The influence of polyamines, mostly putrescine, on the somatic embryogenesis phase has been stated in Eucalyptus [118]. The increase in putrescine concentration $(28.36 \mu \mathrm{M})$ in the culture media of E. grandis $\times$ E. urophylla provided a higher percentage of somatic embryogenesis induction. Combination of putrescine and BAP in the media increased the number of somatic pro-embryos [104,119].

\subsection{Role of Auxins in Somatic Embryogenesis}

Induction of SE is among the most vital steps in the micropropagation technique and has been frequently tackled by the researchers. Nonetheless, low levels of embryogenic initiation, maturity, germination, as well as the occurrence of somaclonal variations are the most important internal hurdles 
in recalcitrant plant species such as Eucalyptus [14,32,106]. In the initial phase of somatic embryogenesis, various stimulus can trigger different mechanisms to achieve embryo development in plants (Figure 4).

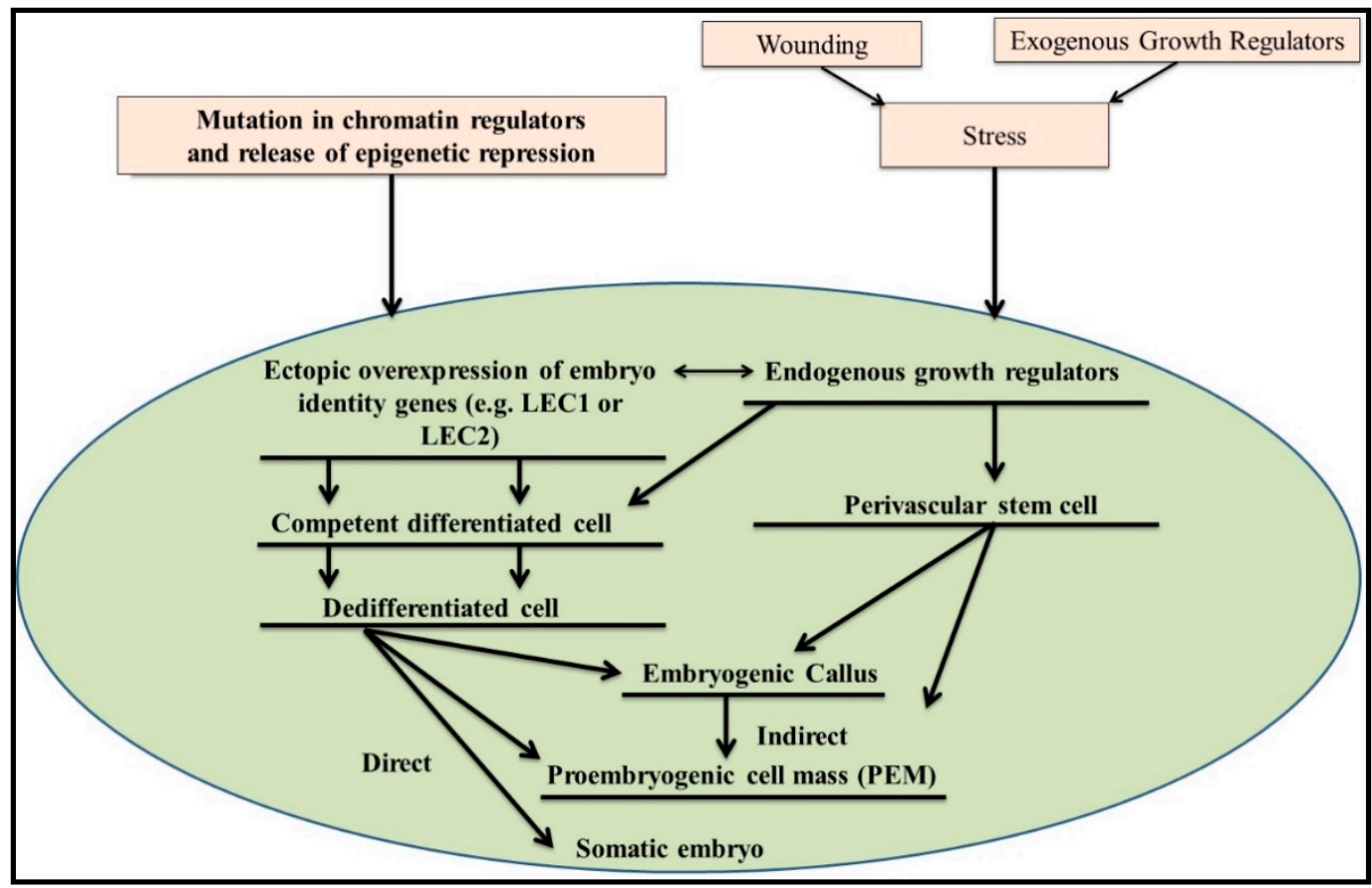

Figure 4. The diverse routes of SE in Eucalyptus. The embryogenic mechanisms can be initiated in perivascular cells through the formation of callus/PEM or in differentiated cells directly or indirectly. Exogenous (stress, wounding, PGRs alone or combined) and endogenous or signals cause an unbalanced cellular hormone level leading to competent cells dedifferentiation followed by direct embryogenesis or over-proliferation and callus tissue differentiation. Under further signals, cells of the embryogenic calli can also go through embryogenesis. Mutations in genes repressing embryo development in vegetative cells and/or the ectopic expression of transcription factors responsible for meristem/embryo identity can also result in embryo differentiation from competent cells.

The effectiveness and pathway of SE differentiation depends on several factors; however, optimum concentrations of PGRs play a vital function in the acquisition of cellular competence, initiating dedifferentiation, and re-differentiation [113]. At the cellular level of Eucalyptus plants, auxins are able to regulate different mechanisms such as cell division, expansion, and differentiation, and auxins can promote isodiametric expansion, lateral expansion, and axial elongation [30,52]. Furthermore, synthetic auxins such as 2,4-D, 4-amino-3,5,6-trichloropicolinic acid (picloram) and dicamba disrupt endogenous auxin metabolism, promote cellular reorganisation and induce somatic embryogenesis $[10,37,53]$.

Nonetheless, constant disclosure of the Eucalyptus explant to the PGRs (especially auxins such as NAA and 2,4-D) has an adverse impact on the physiology and morphology of propagated plants, such as fasciation, dwarfism, hyperhydricity, somaclonal variation, or structure distortion $[38,82,103]$. During SE initiation, auxins play an important role in a stress component and auxin signaling and could change the auxin content in Eucalyptus $[27,103,120]$. The positive interaction of the oxidation of callogenic tissue with embryogenic calli formation has been reported in cotyledonary of E. urophylla $\times$ E. grandis [52]. Among all the PGRs (especially auxins), NAA has been frequently applied for SE induction in Eucalyptus species [13,110,121,122]. Although 2,4-D is a popular phytohormone used in SE induction, picloram was found to be more effective and stronger auxin in SE in case of Eucalyptus species $[119,123]$. In the cultivated explants in MS media supplemented with 2,4-D, an increase in the level of endogenous auxins was observed in the explants and consequently enhanced cell division. 
However, the initiation of SE is dependent on different factors especially the negative gradient of 2,4-D concentration [124].

\section{Influence of Environmental and External Factors on Micropropagation of Eucalyptus}

Like other plant species, micropropagation in Eucalyptus is severely influenced by physic-chemical factors, culture media, nutrients, and PGRs [125]. In the following section, the most important factors influencing the Eucalyptus micropropagation are discussed.

\subsection{Effect of Media}

Over the decades, Murashige and Skoog (MS) media and their modified versions have been reported as the most suitable basal media for Eucalyptus propagation under in vitro condition [24]. However, MS media were not found to be efficient media for some of the Eucalyptus explants such as the canopy branch (CB) shoots (excessive multiplication with a reduction in hyperhydricity and leaf growth which may lead to an increase in the dry mass) and trunk base (TB) shoots (high oxidation) $[119,126,127]$. The MS medium is assumed as a possible chemical agent due to its high concentration of salt, which confirms the archived results in the CB shoots of Eucalyptus. Hyperhydricity may be caused by the interaction of some explants with MS media during micropropagation of Eucalyptus. Absence in $\mathrm{TB}$, high intensity of $\mathrm{CB}$, and high number of hyperhydric shoots were observed from apical meristems rather than in nodal segments [128]. Nonetheless, other types of plant basal media with lower ionic strength such as Juan, Antonio, Diva and Silvia (JADS) and woody plant medium (WPM) have been used for Eucalyptus hybrids and species [97,129]. It has been reported that WPM is the optimum media for organogenesis, adventitious buds, CB shoots multiplication, and callus formation in E. benthamii $[130,131]$. Reportedly, the induction of higher CB shoots was due to the essential abilities of each organ or tissue in the WPM media [27,103]. However, trunk base shoots of E. grandis were found to grow and multiply better in JADS media due to higher dry mass, a low rate of oxidation, and improved morphological feathers $[132,133]$. E. dunnii basal medium (EDM) and its modified version (EDMm) were reported as the most suitable media for organogenesis and plant regeneration of E. dunnii juvenile material [97,129]. In Eucalyptus, the liquid medium supported better shoot proliferation as compared to semisolid medium. Additionally, high rate of assimilation and less physical resistance to diffusion were reported during proliferation step of Eucalyptus in liquid medium [134-136].

Reportedly, all the mentioned media have some drawbacks such as low rooting rates, excessive callus formation, hyperhydricity, oxidation (tissues browning or blackening), and chlorosis occurred when applied for different Eucalyptus species/hybrids [129]. Furthermore, abnormal metabolism triggered by nutritional imbalances influences the cell and tissue sensitivities to phytohormones [137]. Oxidation is a phenomenon closely influenced by chemical and mechanical damage in the cultures. Although WPM did not cause any oxidation, MS media exhibited intermediate oxidation. High oxidation and phenolic compounds are also observed in explants of E. globulus and E. urophylla cultivated in JADS medium [138].

\subsection{Importance of Nitrogen, Calcium, Boron, and Colchicine on Micropropagation of Eucalyptus}

Minerals and nutrients such as nitrogen $(\mathrm{N})$, calcium (Ca), and boron (B) play a vital role in in vitro propagation in Eucalyptus [139]. Calcium is a nutrient moderately immobile in plant species, and the calcium uptake is limited under in vitro conditions due to low transpiration level of the explants [140]. The restriction of calcium uptake leads to calcium deficiency in plants growing under in vitro conditions. Hence, the highest level of calcium is desired in the plant tissue culture medium, mostly for those plant species that present shoot tip necrosis or hyperhydricity $[58,68]$. Calcium is involved in cell division, mitosis, and elongation of root primordia, and acts as a second messenger in crucial signalling pathways, particularly those of auxin [38,141]. Ca is a macro element active in the signal transduction pathways under environmental stresses and works as intracellular messengers in various phases of plant development such as embryonic development. It is also associated with 
various physiological processes such as enzymatic activation, reactions with plant growth regulators, ion uptake, and membrane function and structure [142]. In some plant species, increase in cytoplasmic calcium levels influenced embryogenic responses [3].

Boron (B), is a micronutrient also proved to be a critical nutrient for plant growth and health. The key function of boron is the association of this nutrient with the strength and development of cell wall, cell division, hormone development, sugar transport, and seed and fruit development. In plant tissue culture, boron interrelates with calcium, potassium, phosphorus, and nitrogen [143].

It has been reported that the increase in concentrations of $\mathrm{Ca}$ and $\mathrm{B}$ stimulate organogenesis in E. grandis and E. urophylla under in vitro conditions [130,139]. However, the simultaneous omission of both nutrients led to the induction of globular structures and friable callus, inhibited root formation, as well as the occurrence of anthocyanin [144]. Additionally, deficiency of B in the tissue culture system leads to an abnormal induction of adventitious buds, accumulation of callus, necrosis, and phenols in E. grandis [96]. Reportedly, a high morphogenetic potential was observed in the regenerated buds of both E. grandis and E. urophylla forming nodal segments cultivated in MS media added with $0.5 \mathrm{mg} \mathrm{L}^{-1}$ of NAA and BAP and diverse concentrations of Ca and B $[96,130,139]$. Similarly, the dry and fresh weights of Eucalyptus were increased when the plant was cultivated on MS media enriched with the higher concentrations of Ca and B [50,112,113]. Boron deficiency, under ex vitro condition, caused seedling inhibition of E. grandis. Mainly, this inhibition occurred in the meristematic shoots regions, thus helping to impair the lateral and apical buds' initiation [104].

A significant variation of the relative water content (RWC) in the explants is associated with different types of induced cell structure, while the occurrence of callus and proliferation is led by less water retention and an increased accumulation of matter in the Eucalyptus tissues. To protect plants under adverse condition, cells lose their water (autolysis characterises) [144]. Additionally, the exhaustion of minerals in the media could have promoted the callus to develop a chronic lack of nutrient(s) necessary for the metabolism of cells. This deficiency of mineral in tissue culture medium could influence the explants' growth and development and have an impact on different organogenesis factors [145]. The result of investigation on the organogenesis of E. grandis showed a positive interaction between buds or/and callus induction with the $\mathrm{Ca}$ and $\mathrm{B}$ in culture media. However, new genetic and histological studies are expected to discover the mechanisms and pathways of plants treated under Ca and B concentrations in vitro [7,105,130]. Furthermore, a higher level of Ca concentration in the culture media could constrain intercellular transport in Eucalyptus through the block of plasmodesms [3,105].

Colchicine, extracted from Colchicum autumnale, is able to promote polyploidy level in Eucalyptus cells during cellular division by preventing segregation of chromosome during meiosis. Availability of this plant-derived alkaloid leads to the generation of more desirable traits such as fast, hard, and large growth in polyploid plants than the normal diploid parents. Polyploidy is formed in multiple shoot clumps of E. globulus treated in MS media supplemented with $0.5 \%$ colchicine. The leaves of polyploidy $(2 n=4 x=44)$ plants showed a darker green colour with larger and thicker morphology [146].

Organic nitrogen compounds are the most important factors in tissue culture. To date, various ranges and groups of amino acids have been widely contributed as the main resources of nitrogen under in vitro conditions. In comparison to nitrogen from the inorganic sources, the nitrogen from amino acid resources is assimilated rapidly due to the existence of carbonic skeletons during protein synthesis [147,148]. Alanine is a glucogenic hydrophobic and aliphatic amino acid utilised for protein biosynthesis. The supplementation of medium with alanine decreased the shoot number and oxidation percentage of Eucalyptus cloeziana. However, the shoot length and callogenesis percentage did not change significantly $[120,140,144]$. It is generally stated that the need for a particular amino acid can be linked to the genetic potential and the target tissue culture procedure as well as the resistance/tolerance potential of plants against stresses [149]. Notwithstanding the importance of using amino acids for growth and development, sometimes amino acid is considered as a growth inhibitor for plants, especially when a combination of two or more amino acids is supplemented together in the culture medium. For example, inhibition of E. cloeziana in WPM media added with $1 \mathrm{mg} \mathrm{L}^{-1}$ of glycine 
and alanine has been observed due to a negative interaction between the two mentioned amino acids. Additionally, the endogenous amino acids of E. cloeziana have negatively interacted with the alanine $[17,145,150]$.

\subsection{Effect of Carbohydrate}

Carbohydrates are considered as the main source of carbon and energy for growth of plants and provide the optimum conditions by maintaining the osmotic potential of the media [151]. Sucrose is a non-reducing (without a hemiacetal) sugar, composed of fructose and glucose connected via their anomeric carbons [147]. Although various types of carbon resources have been applied for in vitro culture of tree species, sucrose is still a reliable carbon resource applied in Eucalyptus [152]. Sucrose improved the productivity of secondary metabolites and led to cellular differentiation, metabolic shift, and modulation of gene expression [153-155]. Comparing with reducing sugars, sucrose as non-reducing sugar is less active and able to translocate more $[119,140]$. Some reports revealed that high concentration of sucrose might be responsible for the generation of osmotic stress and reduction in the root biomass yield. On the contrary, the growth and yield of some trees were not influenced by various concentrations of sucrose [156]. It has been reported that high concentration of sucrose inhibited the shoot length in E. cloeziana due to the low osmotic potential, which resulted in low nutrients and water uptake $[24,144]$. Visual observation showed the release of phenolic compounds in the presence of higher sucrose concentrations due to the oxidised substances [157]. The literature showed that although E. cloeziana explants are inclinable to oxidise, autoclaving culture media formed the hydroxymethylfurfural (toxic) and inhibits growth [158]. Therefore, it is recommended to utilise the filtering process as an alternative method to avoid oxidation by autoclaving [159]. The high sucrose concentration limits the activity of photosynthesis by decreasing the concentration of the key enzymes in the photosynthesis and chlorophyll $[58,160]$. The reddening phenomenon was observed in shoot leaves multiplied from different explants in medium with high concentrations of sucrose $\left(60 \mathrm{~g} \mathrm{~L}^{-1}\right)$, which is linked with additional production of anthocyanins. The excess production of anthocyanins is connected to the concentrations of sucrose in the tissue culture media [161,162]. However, absence of sucrose inhibits development process due to an insufficient amount of $\mathrm{CO}_{2}$ for the Eucalyptus to fully exert its autotrophism [163].

Glucose, fructose, and galactose are the other energy sources supplemented in media for in vitro propagation of Eucalyptus. Nonetheless, the reactions of Eucalyptus vary against different carbon resources [154,156,164]. Glucose, as a reducing sugar, is able to perform diffusion across the cut surfaces of tissues and also metabolise in tissues [165]. A study on E. cloeziana in a culture medium supplemented with $15 \mathrm{~g} \mathrm{~L}^{-1}$ glucose presented the highest shoot number, high multiplication rate, and low death range due to a decrease in oxidation. The higher level of some carbohydrate resources may lead to an increase in phenolic compounds and oxidation; however, it has been recommended that either using glucose or alternatives such as activated charcoal, ascorbic acid, citric acid, or other antioxidants in medium can decrease the oxidation level in Eucalyptus [58,145,165]. It has been reported that the combination of sucrose and glucose mainly influenced morphogenesis especially during cellular division in Eucalyptus [166]. The increase in sucrose and glucose concentrations (more than $\left.15 \mathrm{~g} \mathrm{~L}^{-1}\right)$ in the culture media decreased the shoot length of E. cloeziana $[68,111]$.

\subsection{Light and Radiation Effect}

Light quality and sources such as a compact fluorescent lamp (CFL) and photosynthetically active radiation (PAR) are the most important factors affecting the different phases of plant growth [167] and development [132]: such as rooting, shoot growth, multiplication, and elongation [92]. It is shown that the mixture of blue $(380$ and $500 \mathrm{~nm})$ and red $(700 \mathrm{~nm})$ light together could boost growth and development of plants by raising the PN (the net photosynthetic rates). The growth rate is due to the spectral energy distribution of blue and red light corresponding with that of the chlorophyll absorption [168]. The radiation spectra of PAR utilised in an investigation produced two main 
booms-i.e., at 650-680 nm wavelengths and 410-450 $\mathrm{nm}$ wavelengths-whereas radiation was in a wide spectrum of 380-660 nm wavelengths in the status of a CFL [169]. Additionally, a significant increase was observed in chlorophyll content of Eucalyptus in cultures incubated under PAR [92,169-171]. The increase in efficiency of rooting under PAR could be due to the influence of blue-light-reacting cryptochromes and red/far-red-light-reacting phytochromes [146,172]. In comparison to a CFL, higher osmotic potential was reported in Eucalyptus species under PAR. Osmotic potential is one of the most vital physiological parameters that influences Eucalyptus survival rate and performance during the adaptation and acclimatisation period $[173,174]$. Osmotic potential of Eucalyptus increased under incubation of PAR [169]. Light is known to regulate the expression [175], and post-translational modification of the nitrate reductase (NR) gene (s) [133], which is associated with impacting water relations [176], and the growth of Eucalyptus [177]. A major restriction in Eucalyptus micropropagation is the high rate of mortality that happens during the acclimatisation phase. High rate of survival, more vigorous growth, and higher chlorophyll contents were observed in Eucalyptus produced under PAR [85]. Higher growth and survival rate of Eucalyptus under PAR following transfer to in vivo was due to the higher level of chlorophyll content, and exclusively because of the modulation of photosynthetic capability [178].

Light intensity (quantity) is associated with photosynthetic activity and changes in vegetative growth, dry matter accumulation, and carbon fixation [179]. Generally, plants under high light intensity produce or develop thicker leaves, which can increase photosynthetic capacity per unit of area, improving the plant's ability to utilize light for carbon fixation [180]. It is shown that the sudden changes in light intensity stimulated rooting [181]. A study on micropropagation of Eucalyptus ficifolia demonstrated that a light intensity of $10 \mu \mathrm{mol} \mathrm{m} \mathrm{m}^{-2} \mathrm{~s}^{-1}$ developed a fibrous root system. Furthermore, incubation of E. ficifolia on media supplemented with riboflavin under a light intensity of $10 \mu \mathrm{mol} \mathrm{m}{ }^{-2} \mathrm{~s}^{-1}$ developed the subsurface roots with either short or no laterals [182]. Reportedly, higher rate of shoot formation and organ regeneration were obtained in Eucalyptus plants under reduced (50\% reduced) or indirect light compared to normal light [183]. In addition, increases in some growth parameters of E. urograndis tissues were reported in response to high light intensity $\left(250 \mu \mathrm{mol} \mathrm{m} \mathrm{m}^{-2} \mathrm{~s}^{-1}\right)$ [184]. On the contrary, Miranda et al. [185] reported that the light quality was more important than the light intensity in the in vitro development of E. urophylla. It is believed that the variations of Eucalyptus responses to light quantity in vitro are largely dependent on the genotype $x$ light $x$ time or genotype $x$ time interactions [186].

Radiation is a critical regulator in plant growth and development. In plants, complex mechanisms have been evolved to interpret radiation-duration, -direction, -quantity, and -quality. By interpreting radiation factors, plants generate the appropriate developmental and physiological responses [187]. Reportedly, radiation could impact the rooting of Eucalyptus in diverse mechanisms. Exposure of E. globulus to the low level of irradiation enhanced the rooting of stem cuttings [188,189]; however, Correela et al. [190] proved that low irradiance was harmful to the rooting of E. globulus. Ruedell et al. [84] demonstrated that there were no influences of far-red, red, blue, and white radiation (radiation quality) on the adventitious rooting of E. globulus (an easy-to-root species) and E. grandis (a recalcitrant species).

\section{Regeneration and Acclimatisation of Eucalyptus}

The regeneration procedure is among the most important bottlenecks preventing the wider application of in vitro mass propagation and genetic modification technologies to the genus Eucalyptus [191]. It is well documented that young seedlings are the ideal tissue for achieving higher rate of regeneration in E. camaldulensis [192]. Reports on E. globules and E. nitens demonstrated that hypocotyl derived calli was more efficient for regeneration than other explants [193]. However, Herve et al. [194] reported the high rate of regeneration in meristems regions of E. gunnii leaves that are closed to the vascular bundles. González et al. [195] suggested that young hypocotyls, mature embryos, and cotyledons of Eucalyptus have been used as the ideal target for deriving biochemical and molecular structures of cells and tissues leading higher percentage of transformation compared to older explants. 
A combination of cytokinins (BAP) and auxins (NAA) in lower concentrations supplemented to MS media promoted direct organogenesis from cotyledons and hypocotyls of E. tereticornis [196,197]. Notwithstanding all the above matters, mature somatic embryos of different Eucalyptus species habitually do not grow in the media supplemented with auxin. On the other hand, Eucalyptus emblings (regeneration) have been frequently completed in an auxin-free culture medium or, rarely, in the culture media supplemented with gibberellic acid (GA3) and/or cytokinin $[13,32]$ (Table 1). 
Table 1. Some examples of Eucalyptus regeneration in different culture conditions [32].

\begin{tabular}{|c|c|c|c|c|c|c|c|c|c|}
\hline Species & BM & $\begin{array}{l}\text { PGR or Other } \\
\text { Supplements }\end{array}$ & Explant & Soma-Clonal & $\begin{array}{c}\text { Light } \\
\text { Conditions }\end{array}$ & $\begin{array}{l}\text { Response } \\
\text { Variation }\end{array}$ & $\begin{array}{c}\text { Acclimati } \\
\text { Sation }\end{array}$ & Other Studies & References \\
\hline E. globulus & MS and B5 & $\begin{array}{l}\text { PGR free, BAP, } \\
\text { Kinetin }\end{array}$ & $\begin{array}{c}\text { Secondary } \\
\text { somatic } \\
\text { embryo }\end{array}$ & $\mathrm{Nd}$ & Dark and L & Germination & no & - & [13] \\
\hline E. globulus & B5 & $\begin{array}{l}\text { NAA and } \\
\text { BAP }\end{array}$ & $\begin{array}{l}\text { Globular } \\
\text { structures }\end{array}$ & $\mathrm{Nd}$ & $16 \mathrm{~h} \mathrm{~L}$ & $\begin{array}{c}\text { Shoot } \\
\text { proliferation }\end{array}$ & No & - & [198] \\
\hline E. citriodora & B5 & PGR free & $\mathrm{EC}$ & $\mathrm{Nd}$ & Continous L & Emblings & Yes & $\begin{array}{c}\text { Somatic } \\
\text { embryo } \\
\text { encapsulation }\end{array}$ & [199] \\
\hline E. dunnii & nd & $\mathrm{Nd}$ & $\mathrm{Nd}$ & $\mathrm{Nd}$ & nd & $\begin{array}{c}\text { Embryo } \\
\text { maturation } \\
\text { and } \\
\text { germination }\end{array}$ & $\mathrm{Nd}$ & $\mathrm{Nd}$ & [200] \\
\hline E. citriodora & B5 & PGR free & $\mathrm{EC}$ & $\mathrm{Nd}$ & $\begin{array}{l}\text { Continuous } \\
\text { L16 h L }\end{array}$ & Emblings & Yes & - & [199] \\
\hline E. globulus & MS & PGR free & $\begin{array}{l}\text { Primary } \\
\text { somatic } \\
\text { embryos }\end{array}$ & $\mathrm{Nd}$ & Dark & Emblings & no & - & [13] \\
\hline E. dunnii & B5 & $\begin{array}{c}10 \% \text { coconut } \\
\text { milk }\end{array}$ & $\mathrm{EC}$ & - & $16 \mathrm{~h} \mathrm{~L}$ & $\begin{array}{l}\text { Embryos with } \\
\text { green } \\
\text { cotyledons }\end{array}$ & - & - & {$[68,201]$} \\
\hline E. tereticornis & MS & PGR free & $\begin{array}{c}\text { Primary } \\
\text { somatic } \\
\text { embryos }\end{array}$ & $\mathrm{Nd}$ & $16 \mathrm{~h} \mathrm{~L}$ & Emblings & Yes & - & {$[22,68,102,201]$} \\
\hline
\end{tabular}


The final aim of the application of somatic embryogenesis is to micropropagate plants accomplished with the success rate of plant acclimatisation to field conditions. Similarly, as the propagated plants should be true-to-type with the suitable traits such as shorter rotation period, uniform quality, and high yield of the donor plants, it is vital to confirm and follow the clonal fidelity as well as field productivity of somatic embryo from plants [202]. As mentioned earlier, different factors influence the root emergence rate of Eucalyptus in the acclimatisation phase. Reportedly, half strength MS media showed a better root elongation in E. camaldulensis. However, a better root emergence is reported on free-hormone B5 media with half-strength salt concentration for E. grandis, E. deglupta, E. camaldulensis, and E. botryoides [127,203-205]. On the other hand, bud emergence from the cotyledonary leaves of E. urophylla $\times$ E. grandis was induced in the SP culture medium supplemented with GA $3, \mathrm{NAA}_{\text {, }}$ and BAP between 20 and 30 days [127]. Additionally, bud elongation from leaves of E. camaldulensis was stimulated when the WPM media containing NAA and BAP were used, and the plant occasionally exhibited spontaneous elongation and rooting [153]. The cultivation of cotyledon leaves on the transverse side of Eucalyptus was performed on hormone-free medium and represented subtended stomata within uniserial epidermis with both upper and lower layers. Palisade parenchyma was arranged in approximately three layers to form the dorsiventral mesophyll, while the vascular bundles were supported by a sheath of parenchyma cells. The first cell division of palisade parenchyma was observed in MS media supplemented with NAA $(2.7 \mu \mathrm{M})$ and BAP $(4.44 \mu \mathrm{M})$ after fifteen days. Subsequently, callus formation was performed in the subepidermal layer, and callogenesis was observed in the tissue of peripherical parenchymatic after thirty days. The intensity of the cellular proliferation broke the adaxial epidermis of some samples, which developed the caulinar meristems in their parenchyma [127]. These results were in parallel with Alves et al. [206] on growth regulators effects on the organogenesis from the E. urophylla $\times$ E. grandis' leaf explants. Their findings revealed that the buds' adventitious region developed on mesophyll of adaxial epidermis' calli in the hybrid explants on BAP $(4.44 \mu \mathrm{M})$ medium after thirty-five days. The exact local understanding of cell divisions starting, due to their superficial origin regarding the induction of adventitious bud, before the formation of callus, is necessary for presenting the genetic transformation [127]. MS medium (supplemented with 2, 4-D and N-(2-chloro-4-pyridyl)-N'-phenylurea (4-CPPU)) induces the development of the adventitious buds from the Racosperma mangium' cotyledons. The anatomical study of adventitious buds showed the highest extreme epidermis differentiation, as well [207]. Stipp at al. [208] described the same results by obtaining adventitious buds in the Cucurbita melo cotyledons' cultures on the MS medium with BAP $(4.44 \mu \mathrm{M})$. In the mentioned case, several meristematic zones were detected near the epidermis. However, after 45 and $60 \mathrm{~d}$ on medium with BAP and NAA, the calli were developed and presented concentric groups of adventitious buds and vascular cells with visible caulinar meristems. The same results were observed in the histological investigation of internode explants, node, and leaf of E. gunnii, cultivated in the presence of BAP $(2.25 \mu \mathrm{M})$ and picloram $(0.04 \mu \mathrm{M})$ [194]. It has been shown that the callus of E. camaldulensis and E. urophylla possesses a limited number of cell divisions before differentiation, which was activated followed by restricted shoot regeneration due to the size of callus $[109,127]$.

\section{Conclusions}

The micropropagation technology has matured to become popular in the biotechnology field where many researchers are looking to establish "recipes" to use in vitro culture. To date, a number of of recipes have been established successfully for several plant species, without special training or adaptation. Nonetheless, there are plenty of plant species where little micropropagation investigation has been performed on them and appropriate protocols may or may not be fully developed. In summary, the current review paper focused on the most relevant physiological advances in the micropropagation of Eucalyptus from the cell to acclimatisation. In this project, we highlighted the inner scenario of the interaction between the internal and external factors which play a role in the tissue culture of Eucalyptus. We also demonstrated that the ability of selected PGRs to form organogenesis and somatic 
embreyogenesis remains the most significant and yet often the most problematic aspect of Eucalyptus propagation. Additionally, our review emphasised the relationship between the key plant growth regulators (auxins, cytokinins, ethylene) and the formation of roots and shoots in correlation with molecular and biochemical events.

On the other hand, we showed that other external factors such as nutrients, nitrogen, calcium, boron, colchicine, carbohydrate, light, and radiation have the regulatory function on the physiological aspects of Eucalyptus plant in vitro conditions. As mentioned, regeneration protocols through organogenesis or somatic embryogenesis need to be optimized depending on specific genotypic requirements. For the majority of woody plants, especially Eucalyptus, the application of tissue culture technology presents many bottlenecks, particularly due to the induction conditions, the genotype, the number of shoot and root, the percentages of shoot and root elongation, the number of embryos produced, the maturation, the regeneration and emblings, and acclimatization rate and performance. The advanced information of the current paper will help researchers to focus on the optimum conditions of Eucalyptus tissue culture based on physiological phenomena. Notwithstanding the large amount of research which has been conducted on the micropropagation of Eucalyptus over the decades, additional investigations are also required to identify, discover, and ultimately overcome some of the current barriers and develop a strategic approach for the industrial purposes.

Author Contributions: R.A., N.A., N.A.A.S., N.A.S. and S.M. developed the ideas, R.A., N.A., R.S. and S.M. contributed the case study data. R.A., N.A., R.S. and S.M. wrote the manuscript, N.A.A.S., H.A.-H. supervision of the project, R.S., S.A.A., H.A.-H., N.A.S. and S.M. editing and proofreading. All authors have read and agreed to the published version of the manuscript.

Funding: This work was supported by Trans-disciplinary Research Grant Scheme (TRGS) 2018 under the Ministry of Higher Education (MOHE), Malaysia. Reference code: TRGS/1/2018/UPM/01/2/2.

Conflicts of Interest: The authors report no declarations of interest.

\section{References}

1. Batista, T.R.; Mendonase, E.G.; Padua, M.S.; Stein, V.C.; Paiva, L. Morpho and cytological differentiation of calli of Eucalyptus grandis x Eucalyptus urophylla during somatic embryogenesis. Braz. Arch. Biol. Technol. 2018, 61, 1-11. [CrossRef]

2. Merkle, S.A.; Nairn, C.J. Hardwood tree biotechnology. In Vitro Cell. Dev. Biol. Plant. 2005, 41, $602-619$. [CrossRef]

3. Nogueira, M.C.D.J.A.; de Araujo, V.A.; Vasconcelos, J.S.; Christoforo, A.L.; Lahr, F.A.R. Sixteen properties of Eucalyptus Tereticornis wood for structural uses. Bioscience 2020, 36, 449-457. [CrossRef]

4. $\quad$ Rezende, G.D.S.; de Resende, M.D.V.; de Assis, T.F. Eucalyptus breeding for clonal forestry. In Challenges and Opportunities for the World's Forests in the 21st Century; Springer: Berlin/Heidelberg, Germany, 2014; pp. 393-424.

5. Benra, F.; Nahuelhual, L.; Gaglio, M.; Gissi, E.; Aguayo, M.; Jullian, C.; Bonn, A. Ecosystem services tradeoffs arising from non-native tree plantation expansion in southern Chile. Landsc. Urban Plan. 2019, 190, 1-19. [CrossRef]

6. Dhakad, A.K.; Pandey, V.V.; Beg, S.; Rawat, J.M.; Singh, A. Biological, medicinal and toxicological significance of Eucalyptus leaf essential oil: A review. J. Sci. Food Agric. 2018, 98, 833-848. [CrossRef] [PubMed]

7. Hirsch, H.; Allsopp, M.H.; Canavan, S.; Cheek, M.; Geerts, S.; Geldenhuys, C.J.; Harding, G.; Hurley, B.P.; Jones, W.; Keet, J.H. Eucalyptus camaldulensis in South Africa- "past, present, future". Trans. R. Soc. S. Afr. 2020, 75, 1-22. [CrossRef]

8. Kerk, N.M.; Jiang, K.; Feldman, L.J. Auxin metabolism in the root apical meristem. Plant Physiol. 2000, 122, 925-932. [CrossRef]

9. Stokes, A.; Atger, C.; Bengough, A.G.; Fourcaud, T.; Sidle, R.C. Desirable plant root traits for protecting natural and engineered slopes against landslides. Plant Soil 2009, 324, 1-30. [CrossRef] 
10. Monteuuis, O. Vegetatively propagating forest trees. In Proceedings of the Fourth International Conference of the IUFRO Unit 2.09.02 on “Development and Application of Vegetative Prpagation Technologiesd in Plantation Forestry Cope with a Changing Climate and Environemnt", La Plata, Argentina, 19-23 September 2016; pp. 37-57.

11. Naidoo, S.; Slippers, B.; Plett, J.M.; Coles, D.; Oates, C.N. The road to resistance in forest trees. Front. Plant Sci. 2019, 10, 273. [CrossRef]

12. Nakhooda, M.; Watt, M.P.; Mycock, D. The choice of auxin analogue for in vitro root induction influences post-induction root development in Eucalyptus grandis. Turk. J. Agric. For. 2014, 38, 258-266. [CrossRef]

13. Pinto, G.; Park, Y.; Neves, L.; Araujo, C.; Santos, C. Genetic control of somatic embryogenesis induction in Eucalyptus globulus Labill. Plant Cell Rep. 2008, 27, 1093-1101. [CrossRef] [PubMed]

14. Jain, S.M. An updated overview of advances in somatic embryogenesis in forest trees. In Plantation Technology in Tropical Forest Science; Springer: Berlin/Heidelberg, Germany, 2006; pp. 113-122.

15. Hussain, A.; Qarshi, I.A.; Nazir, H.; Ullah, I. Plant Tissue Culture: Current Status and Opportunities. Recent Advances in Plant In Vitro Culture; Leva, A., Ed.; InTech: London, UK, 2012; pp. 1-28.

16. Girijashankar, V.; Sharma, K.; Balakrishna, P.; Seetharama, N. Direct somatic embryogenesis and organogenesis pathway of plant regeneration can seldom occur simultaneously within the same explant of sorghum. J. SAT Agric. Res. 2007, 3, 1-3.

17. Stewart, C.N., Jr. Plant Biotechnology and Genetics: Principles, Techniques, and Applications; John Wiley \& Sons: Hoboken, NJ, USA, 2016.

18. Johns, A.E. Lessons for Plant Micropropagation; Educreation Publishing: Chhattisgarh, India, 2019; p. 85.

19. Trueman, S.J.; Hung, C.D.; Wendling, I. Tissue culture of Corymbia and Eucalyptus. Forests 2018, 9, 84. [CrossRef]

20. Kendurkar, S.V.; Rangaswamy, M. In Vitro Approaches for the Improvement of Eucalyptus. In Biotechnologies of Crop Improvement; Springer: Berlin/Heidelberg, Germany, 2018; pp. 159-214.

21. Arya, I.; Chauhan, S.S.S.; Arya, S. Micropropagation of superior Eucalyptus hybrids FRI-5 (Eucalyptus camaldulensis Dehn x E. tereticornis Sm) and FRI-14 (Eucalyptus torelliana FV Muell x E. citriodora Hook): A commercial multiplication and field evaluation. Afr. J. Biotechnol. 2009, 8, 5718-5726.

22. Prakash, M.; Gurumurthi, K. Effects of type of explant and age, plant growth regulators and medium strength on somatic embryogenesis and plant regeneration in Eucalyptus camaldulensis. Plant Cell Tissue Organ Cult. 2010, 100, 13-20. [CrossRef]

23. Guerra, M.; Fraga, H.; Vieira, L.; Ree, J.; Heringer, A.; Maldonado, S.B. Fundamentals, advances and applications of somatic embryogenesis in selected Brazilian native species. Acta Hortic. 2016, 1113, 1-12. [CrossRef]

24. Kundu, S.; Gantait, S. Fundamental facets of somatic embryogenesis and its applications for advancement of peanut biotechnology. In Biotechnologies of Crop Improvement; Springer: Berlin/Heidelberg, Germany, 2018; pp. 267-298.

25. Nazir, M.; Sadat, S.; Soltani Howyzeh, M. The effect of different hormone combinations on direct and indirect somatic embryogenesis in Agave americana. Plant Physiol. 2019, 9, 2739-2747.

26. Ochatt, S.J.; Abirached-Darmency, M. The underlying processes governing seed size plasticity: Impact of endoploidy on seed coat development and cell expansion in Medicago truncatula. In The Model Legume Medicago truncatula, 1st ed.; de Bruijn, F.J., Ed.; John Wiley \& Sons, Inc.: London, UK, 2020; pp. 99-115.

27. Elmeer, K.E.S. Factors regulating somatic embryogenesis in plants. In Somatic Embryogenesis and Gene Expression; Narosa Publishing House: New Delhi, India, 2013; pp. 56-81.

28. Martinez, M.T.; San Jose, M.D.C.; Arrillaga, I.; Cano, V.; Morcillo, M.; Cernadas, M.J.; Corredoira, E. Holm oak somatic embryogenesis: Current status and future perspectives. Front. Plant Sci. 2019, 10, 1-14. [CrossRef]

29. Lelu-Walter, M.A.; Thompson, D.; Harvengt, L.; Sanchez, L.; Toribio, M.; Paques, L.E. Somatic embryogenesis in forestry with a focus on Europe: State-of-the-art, benefits, challenges and future direction. Tree Genet. Genom. 2013, 9, 883-899. [CrossRef]

30. Moura, L.C.D.; Xavier, A.; Cruz, A.C.F.D.; Gallo, R.; Gatti, K.C.; Miranda, N.A.; Otoni, W.C. Effects of explant type, culture media and picloram and dicamba growth regulators on induction and proliferation of somatic embryos in Eucalyptus grandis x E urophylla1. Rev. Árvore 2017, 41, 1-10. [CrossRef] 
31. Carraro, N.; Tisdale-Orr, T.E.; Clouse, R.M.; Knoller, A.S.; Spicer, R. Diversification and expression of the PIN, AUX/LAX, and ABCB families of putative auxin transporters in Populus. Front. Plant Sci. 2012, 3, 17. [CrossRef] [PubMed]

32. Pinto, G.; Park, Y.S.; Loureiro, J.; Neves, L.; Araujo, C.; Silva, S.; Santos, C. Somatic embryogenesis in Eucalyptus -an update to 2009. Appl. Plant Biotechnol. In Vitro Propagat. Plant Transf. Second. Metabol. Prod. 2009, 1, 531-542.

33. Hiti-Bandaralage, J.C.; Hayward, A.; Mitter, N. Micropropagation of avocado (Persea americana Mill.). Am. J. Plant Sci. 2017, 8, 2898. [CrossRef]

34. Nourissier, S.; Monteuuis, O. In vitro rooting of two Eucalyptus urophylla x Eucalyptus grandis mature clones. In Vitro Cell. Dev. Biol. Plant. 2008, 44, 263-272. [CrossRef]

35. George, E.F.; Hall, M.A.; De Klerk, G.J. Plant Propagation by Tissue Culture: Volume 1. The Background; Springer Science \& Business Media: Berlin/Heidelberg, Germany, 2007.

36. Nakhooda, M.; Jain, S.M. A review of Eucalyptus propagation and conservation. Propag. Ornam. Plants. 2016, 16, 101-119.

37. Mokotedi, M.E.; Watt, M.; Pammenter, N. Analysis of differences in field performance of vegetatively andseed-propagated Eucalyptus varieties II: Vertical uprooting resistance. South For. 2010, 72, 31-36. [CrossRef]

38. Geiss, G.; Gutierrez, L.; Bellini, C. Adventitious root formation: New insights and perspectives. Annu. Rev. Plant Biol. 2018, 37, 127-156.

39. Da Costa, C.T.; De Almeida, M.R.; Ruedell, C.M.; Schwambach, J.; Maraschin, F.D.S.; Fett-Neto, A.G. When stress and development go hand in hand: Main hormonal controls of adventitious rooting in cuttings. Front. Plant Sci. 2013, 4, 1-19. [CrossRef] [PubMed]

40. Vilasboa, J.; Da Costa, C.T.; Fett-Neto, A.G. Rooting of eucalypt cuttings as a problem-solving oriented model in plant biology. PBMB 2019, 146, 85-97. [CrossRef]

41. Druege, U.; Franken, P.; Hajirezaei, M.R. Plant hormone homeostasis, signaling, and function during adventitious root formation in cuttings. Front. Plant Sci. 2016, 7, 1-14. [CrossRef]

42. Nakhooda, M.; Watt, M. Adventitious root formation in Eucalyptus: The role of phytohormones. Acta Hortic. 2015, 1155, 505-512.

43. Wang, H.; Inukai, Y.; Yamauchi, A. Root development and nutrient uptake. Crit. Rev. Plant Sci. 2006, 25, 279-301. [CrossRef]

44. Nakhooda, M.; Watt, M.P.; Mycock, D. The properties and interaction of auxins and cytokinins influence rooting of shoot cultures of Eucalyptus. Afr. J. Biotechnol. 2012, 11, 16568-16578.

45. Rashotte, A.M.; Brady, S.R.; Reed, R.C.; Ante, S.J.; Muday, G.K. Basipetal auxin transport is required for gravitropism in roots of Arabidopsis. Plant Physiol. 2000, 122, 481-490. [CrossRef] [PubMed]

46. Dolan, L.; Davies, J. Cell expansion in roots. Curr. Opin. Plant Biol. 2004, 7, 33-39. [CrossRef] [PubMed]

47. Nakhooda, M.; Watt, M.P.; Mycock, D. Auxin stability and accumulation during in vitro shoot morphogenesis influences subsequent root induction and development in Eucalyptus grandis. Plant Growth Regul. 2011, 65, 263-271. [CrossRef]

48. Mokany, K.; Raison, R.J.; Prokushkin, A.S. Critical analysis of root: Shoot ratios in terrestrial biomes. Glob. Chang. Biol. 2006, 12, 84-96. [CrossRef]

49. Jacobs, D.; Salifu, K.; Seifert, J. Relative contribution of initial root and shoot morphology in predicting field performance of hardwood seedlings. New For. 2005, 30, 235-251. [CrossRef]

50. Gregory, P.J. Plant Roots: Growth, Activity and Interactions with the Soil; John Wiley \& Sons: Hoboken, NJ, USA, 2008.

51. Nic-Can, G.I.; Loyola-Vargas, V.M. The role of the auxins during somatic embryogenesis. In Somatic Embryogenesis: Fundamental Aspects and Applications; Springer: Berlin/Heidelberg, Germany, 2016; pp. 171-182.

52. Moura, L.C.D.; Xavier, A.; Cruz, A.C.F.D.; Gallo, R.; Miranda, N.A.; Otoni, W.C. Auxin pulse in the induction of somatic embryos of Eucalyptus. Rev. Árvore 2019, 43, 1-12. [CrossRef]

53. Feher, A.; Pasternak, T.P.; Dudits, D. Transition of somatic plant cells to an embryogenic state. Plant Cell Tissue Organ Cult. 2003, 74, 201-228. [CrossRef]

54. Aloni, R.; Aloni, E.; Langhans, M.; Ullrich, C. Role of cytokinin and auxin in shaping root architecture: Regulating vascular differentiation, lateral root initiation, root apical dominance and root gravitropism. Ann. Bot. 2006, 97, 883-893. [CrossRef] 
55. Swarup, R.; Bennett, M.J. Root gravitropism. Annu. Rev. Plant Biol. 2018, 37, 157-174. [CrossRef]

56. Woodward, A.W.; Bartel, B. Auxin: Regulation, action, and interaction. Ann. Bot. 2005, 95, 707-735. [CrossRef] [PubMed]

57. Schneider, E.A.; Gibson, R.; Wightman, F. Biosynthesis and metabolism of indol-3yl-acetic acid: I. The native indoles of barley and tomato shoots. JExB 1972, 23, 152-170. [CrossRef]

58. Tromas, A.; Perrot-Rechenmann, C. Recent progress in auxin biology. Comptes Rendus Biol. 2010, 333, $297-306$. [CrossRef] [PubMed]

59. Ludwig-MUller, J. Indole-3-butyric acid in plant growth and development. Plant Growth Regul. 2000, 32, 219-230. [CrossRef]

60. Wiesman, Z.; Riov, J.; Epstein, E. Characterization and rooting ability of indole-3-butyric acid conjugates formed during rooting of mung bean cuttings. Plant Physiol. 1989, 91, 1080-1084. [CrossRef] [PubMed]

61. Epstein, E.; Ludwig-Muller, J. Indole-3-butyric acid in plants: Occurrence, synthesis, metabolism and transport. Physiol. Plant 1993, 88, 382-389. [CrossRef]

62. Kevers, C.; Hausman, J.F.; Faivre-Rampant, O.; Dommes, J.; Gaspar, T. What we have learned about the physiology of in vitro adventitious rooting of woody plants and how it is relates to improvements in the practice. In Adventitious Root Formation of Forest Trees and Horticultural Plants-From Genes to Applications; Niemi, K., Ed.; Research Signpost: Trivandrum, India, 2009; pp. 400-417.

63. George, E.F.; Hall, M.A.; De Klerk, G.J. Plant tissue culture procedure-background. In Plant Propagation by Tissue Culture; Springer: Berlin/Heidelberg, Germany, 2008; pp. 1-28.

64. Verstraeten, I.; Schotte, S.; Geelen, D. Hypocotyl adventitious root organogenesis differs from lateral root development. Front. Plant Sci. 2014, 5, 1-13. [CrossRef]

65. Won, C.; Shen, X.; Mashiguchi, K.; Zheng, Z.; Dai, X.; Cheng, Y.; Kasahara, H.; Kamiya, Y.; Chory, J.; Zhao, Y. Conversion of tryptophan to indole-3-acetic acid by TRYPTOPHAN AMINOTRANSFERASES OF ARABIDOPSIS and YUCCAs in Arabidopsis. Proc. Natl. Acad. Sci. USA 2011, 108, 18518-18523. [CrossRef]

66. Rambaran, N. Survival and rooting of selected vegetatively propagated Eucalyptus clones in relation to supplied auxin. In Life Sciences, College of Agriculture, Engineering and Scienc; University of KwaZulu-Natal: Durban, South Africa, 2013; p. 84.

67. Irvani, N.; Solouki, M.; Omidi, M.; Zare, A.; Shahnazi, S. Callus induction and plant regeneration in Dorem ammoniacum D., an endangered medicinal plant. Plant Cell Tissue Organ Cult 2010, 100, 293-299. [CrossRef]

68. Traas, J. Organogenesis at the shoot apical meristem. Plants 2019, 8, 6. [CrossRef] [PubMed]

69. Ayala, P.G.; Brugnoli, E.A.; Luna, C.V.; Gonzalez, A.M.; Pezzutti, R.; Sansberro, P.A. Eucalyptus nitens plant regeneration from seedling explants through direct adventitious shoot bud formation. Trees 2019, 33, 1667-1678. [CrossRef]

70. Baltierra, X.C.; Montenegro, G.; De Garcia, E. Ontogeny of in vitro rooting processes in Eucalyptus globulus. In Vitro Cell. Dev. Biol. Plant 2004, 40, 499-503. [CrossRef]

71. Pernisova, M.; Klma, P.; Horak, J.; Valkova, M.; Malbeck, J.; Soucek, P.; Reichman, P.; Hoyerova, K.; Dubova, J.; Friml, J. Cytokinins modulate auxin-induced organogenesis in plants via regulation of the auxin efflux. Proc. Natl. Acad. Sci. USA 2009, 106, 3609-3614. [CrossRef] [PubMed]

72. Su, Y.H.; Liu, Y.B.; Zhang, X.S. Auxin-cytokinin interaction regulates meristem development. Mol. Plant 2011, 4, 616-625. [CrossRef] [PubMed]

73. Moore, I. Gravitropism: Lateral thinking in auxin transport. Curr. Biol. 2002, 12, R452-R454. [CrossRef]

74. Muday, G.K. Auxins and tropisms. J. Plant Growth Regul. 2001, 20, 226-243. [CrossRef]

75. Geldner, N.; Friml, J.; Stierhof, Y.D.; JUrgens, G.; Palme, K. Auxin transport inhibitors block PIN1 cycling and vesicle trafficking. Nature 2001, 413, 425-428. [CrossRef]

76. Aumond, M.L., Jr.; de Araujo, A.T., Jr.; de Oliveira Junkes, C.F.; de Almeida, M.R.; Matsuura, H.N.; de Costa, F.; Fett-Neto, A.G. Events associated with early age-related decline in adventitious rooting competence of Eucalyptus globulus Labill. Front. Plant Sci. 2017, 8, 1734. [CrossRef]

77. Guan, L.; Murphy, A.S.; Peer, W.A.; Gan, L.; Li, Y.; Cheng, Z.M. Physiological and molecular regulation of adventitious root formation. Crit. Rev. Plant Sci. 2015, 34, 506-521. [CrossRef]

78. Jin, Y.; Zhang, C.; Liu, W.; Tang, Y.; Qi, H.; Chen, H.; Cao, S. The alcohol dehydrogenase gene family in melon (Cucumis melo L.): Bioinformatic analysis and expression patterns. Front. Plant Sci. 2016, 7, 670. [CrossRef] [PubMed]

79. Douady, S.; Couder, Y. The F-box protein TIR1 is an auxin receptor. Nature 1992, 68, 441-445. 
80. Grones, P.; Chen, X.; Simon, S.; Kaufmann, W.A.; De Rycke, R.; Nodzynski, T.; Zazimalova, E.; Friml, J. Auxin-binding pocket of ABP1 is crucial for its gain-of-function cellular and developmental roles. JExB 2015, 66, 5055-5065. [CrossRef] [PubMed]

81. Sheng, L.; Hu, X.; Du, Y.; Zhang, G.; Huang, H.; Scheres, B.; Xu, L. Non-canonical WOX11-mediated root branching contributes to plasticity in Arabidopsis root system architecture. Development 2017, 144, 3126-3133. [CrossRef] [PubMed]

82. Hayashi, K.I. The interaction and integration of auxin signaling components. Plant Cell Physiol. 2012, 53, 965-975. [CrossRef] [PubMed]

83. De Almeida, M.R.; Ruedell, C.M.; Ricachenevsky, F.K.; Sperotto, R.A.; Pasquali, G.; Fett-Neto, A.G. Reference gene selection for quantitative reverse transcription-polymerase chain reaction normalization during in vitro adventitious rooting in Eucalyptus globulus Labill. BMC Mol. Biol. 2010, 11, 1-12. [CrossRef]

84. Ruedell, C.M.; de Almeida, M.R.R.; Schwambach, J.L.; Posenato, C.F.; Fett-Neto, A.G. Pre and post-severance effects of light quality on carbohydrate dynamics and microcutting adventitious rooting of two Eucalyptus species of contrasting recalcitrance. Plant Growth Regul. 2013, 69, 235-245. [CrossRef]

85. Aggarwal, D.; Kumar, A.; Sharma, J.; Reddy, M.S. Factors affecting micropropagation and acclimatization of an elite clone of Eucalyptus tereticornis Sm. In Vitro Cell Dev Biol. 2012, 48, 521-529. [CrossRef]

86. Silva de Oliveira, L.; Brondani, G.E.; Batagin-Piotto, K.D.; Calsavara, R.; Gonçalves, A.N.; de Almeida, M. Micropropagation of Eucalyptus cloeziana mature trees. Aust. For. 2015, 78, 219-231. [CrossRef]

87. Brondani, G.E.; Dutra, L.F.; Wendling, I.; Grossi, F.; Hansel, F.A.; Araujo, M.A. Micropropagation of an Eucalyptus hybrid (Eucalyptus benthamii x Eucalyptus dunnii). Acta Sci. Agron. 2011, 3, 655-663. [CrossRef]

88. Ricci, A.; Bertoletti, C. Urea derivatives on the move: Cytokinin-like activity and adventitious rooting enhancement depend on chemical structure. Plant Biol. 2009, 11, 262-272. [CrossRef] [PubMed]

89. Rolli, E.; Incerti, M.; Brunoni, F.; Vicini, P.; Ricci, A. Structure-activity relationships of N-phenyl-N'-benzothiazol-6-ylurea synthetic derivatives: Cytokinin-like activity and adventitious rooting enhancement. Phytochemistry 2012, 74, 159-165. [CrossRef] [PubMed]

90. Romanov, G.A.; Lomin, S.N.; Schmilling, T. Cytokinin signaling: From the ER or from the PM? That is the question! New Phytol. 2018, 218, 41-53. [CrossRef] [PubMed]

91. Huang, Z.; Ouyang, L.; Li, Z.; Zeng, F. A urea-type cytokinin, 2-Cl-PBU, stimulates adventitious bud formation of Eucalyptus urophylla by repressing transcription of rboh1 gene. Plant Cell Tissue Organ Cult. 2014, 119, 359-368. [CrossRef]

92. Lee, S.H.; Tewari, R.K.; Hahn, E.J.; Paek, K.Y. Photon flux density and light quality induce changes in growth, stomatal development, photosynthesis and transpiration of Withania somnifera (L.) Dunal. plantlets. Plant Cell Tissue Organ Cult. 2007, 90, 141-151. [CrossRef]

93. Li, X.-S.; Wang, D.-H. Suppression of thermogenic capacity during reproduction in primiparous Brandt's voles (Microtus brandtii). J. Therm. Biol. 2005, 30, 431-436. [CrossRef]

94. Huang, Z.; Li, H. Control of oxidative stress by a combination of PBU, BAP and DMTU enhances adventitious shoot formation in Eucalyptus urophylla. Plant Cell Tissue Organ Cult. 2020, 141, 533-541. [CrossRef]

95. Huang, Z.C.; Zeng, F.H.; Lu, X.Y. Efficient regeneration of Eucalyptus urophylla from seedling-derived hypocotyls. Biol. Plantarum 2010, 54, 131-134. [CrossRef]

96. Brunoni, F.; Rolli, E.; Dramis, L.; Incerti, M.; Abarca, D.; Pizarro, A.; Diaz-Sala, C.; Ricci, A. Adventitious rooting adjuvant activity of 1, 3-di (benzo [d] oxazol-5-yl) urea and 1, 3-di (benzo [d] oxazol-6-yl) urea: New insights and perspectives. Plant Cell Tissue Organ Cult. 2014, 118, 111-124. [CrossRef]

97. Oberschelp, G.P.J.; Goncalves, A.N.; Meneghetti, E.C.; Graner, A.M.; de Almeida, M. Eucalyptus dunnii Maiden plant regeneration via shoot organogenesis on a new basal medium based on the mineral composition of young stump shoots. In Vitro Cell. Dev. Biol. Plant 2015, 51, 626-636. [CrossRef]

98. Overvoorde, P.; Fukaki, H.; Beeckman, T. Auxin control of root development. Cold Spring Harbor Perspect. Biol. 2010, 2, 1-17. [CrossRef] [PubMed]

99. PamfilL, D.; Bellini, C. Auxin control in the formation of adventitious roots. Not. Bot. Horti Agrob. Cluj Napoca 2011, 39, 307-316.

100. Feher, A. Why somatic plant cells start to form embryos? In Somatic Embryogenesis; Springer: Berlin/Heidelberg, Germany, 2005; pp. 85-101.

101. Picoli, E.D.T. Growth regulators pulsing pre-treatment effect on the Eucalyptus grandis shoot and adventitious root morphogenesis. Plant Cell Cult. Micropropag. 2006, 2, 20-28. 
102. Prakash, M.; Gurumurthi, K. Somatic embryogenesis and plant regeneration in Eucalyptus tereticornis Sm. Curr. Sci. 2005, 88, 1311-1316.

103. Esposito-Polesi, N.P.; de Oliveira, L.S.; Baccarin, F.J.B.; de Almeida, C.V.; de Almeida, M. Different culture conditions applied to in vitro shoot multiplication of two Eucalyptus benthamii explant sources. J. For. Res. 2020, 31, 857-869. [CrossRef]

104. De Mattos Barretto, V.C.; Valeri, S.V.; de Arruda Silveira, R.L.V.; Takahashi, E.N. Efficiency of boron use in the growth of Eucalyptus clones in pots. Sci. For. For. Sci. 2007, 76, 21-33.

105. De Moura, L.C.; Xavier, A.; da Cruz, A.C.F.; Batista, D.S.; Gallo, R.; Miranda, N.A.; Otoni, W.C. Effect of calcium, BAP and putrescine on somatic embryo induction in juvenile explants of Eucalyptus grandis $\times E$. urophylla hybrids. Aust. J. Crop Sci. 2019, 13, 513. [CrossRef]

106. Kaur, G.; Sharma, A.; Guruprasad, K.; Pati, P.K. Versatile roles of plant NADPH oxidases and emerging concepts. Biotechnol. Adv. 2014, 32, 551-563. [CrossRef]

107. Mittler, R.; Vanderauwera, S.; Suzuki, N.; Miller, G.; Tognetti, V.B.; Vandepoele, K.; Gollery, M.; Shulaev, V.; Van Breusegem, F. ROS signaling: The new wave? Trends Plant Sci. 2011, 16, 300-309. [CrossRef] [PubMed]

108. Tian, M.; Gu, Q.; Zhu, M. The involvement of hydrogen peroxide and antioxidant enzymes in the process of shoot organogenesis of strawberry callus. Plant Sci. 2003, 165, 701-707. [CrossRef]

109. Tibok, A.; Blackhall, N.; Power, J.; Davey, M. Optimized plant regeneration from callus derived from seedling hypocotyls of Eucalyptus urophylla. Plant Sci. 1995, 110, 139-145. [CrossRef]

110. Pinto, G.; Araujo, C.; Santos, C.; Neves, L. Plant regeneration by somatic embryogenesis in Eucalyptus spp.: Current status and future perspectives. South For. 2013, 75, 59-69. [CrossRef]

111. Ribeiro, C.W.; Korbes, A.P.; Garighan, J.A.; Jardim-Messeder, D.; Carvalho, F.E.; Sousa, R.H.; Caverzan, A.; Teixeira, F.K.; Silveira, J.A.; Margis-Pinheiro, M. Rice peroxisomal ascorbate peroxidase knockdown affects ROS signaling and triggers early leaf senescence. Plant Sci. 2017, 263, 55-65. [CrossRef] [PubMed]

112. Gonzalez, R.; Rios, D.; Aviles, F.; Sainchez-Olate, M. In vitro multiplication of Eucalyptus globulus by temporary immersion system. Bosque 2011, 32, 147-154. [CrossRef]

113. Grzyb, M.G.; Mikula, A. Explant type and stress treatment determine the uni-and multicellular origin of somatic embryos in the tree fern Cyathea delgadii Sternb. Plant Cell Tissue Organ Cult. 2019, 136, 221-230. [CrossRef]

114. Anjum, N.A.; Sharma, P.; Gill, S.S.; Hasanuzzaman, M.; Khan, E.A.; Kachhap, K.; Mohamed, A.A.; Thangavel, P.; Devi, G.D.; Vasudhevan, P. Catalase and ascorbate peroxidase-representative $\mathrm{H}_{2} \mathrm{O}_{2}$-detoxifying heme enzymes in plants. Environ. Sci. Pollut. Res. 2016, 23, 19002-19029. [CrossRef]

115. Pandey, S.; Fartyal, D.; Agarwal, A.; Shukla, T.; James, D.; Kaul, T.; Negi, Y.K.; Arora, S.; Reddy, M.K. Abiotic stress tolerance in plants: Myriad roles of ascorbate peroxidase. Front. Plant Sci. 2017, 8, 581. [CrossRef] [PubMed]

116. Sukweenadhi, J.; Kim, Y.J.; Rahimi, S.; Silva, J.; Myagmarjav, D.; Kwon, W.S.; Yang, D.C. Overexpression of a cytosolic ascorbate peroxidase from Panax ginseng enhanced salt tolerance in Arabidopsis thaliana. Plant Cell Tissue Organ Cult. 2017, 129, 337-350. [CrossRef]

117. Foreman, J.; Demidchik, V.; Bothwell, J.H.; Mylona, P.; Miedema, H.; Torres, M.A.; Linstead, P.; Costa, S.; Brownlee, C.; Jones, J.D. Reactive oxygen species produced by NADPH oxidase regulate plant cell growth. Nature 2003, 422, 442-446. [CrossRef]

118. Rajesh, M.; Radha, E.; Sajini, K.; Anitha, K. Polyamine-induced somatic embryogenesis and plantlet regeneration in vitro from plumular explants of dwarf cultivars of coconut (Cocos nucifera). Indian J. Agric. Sci. 2014, 84, 527-530.

119. Corredoira, E.; Merkle, S.; Martinez, M.; Toribio, M.; Canhoto, J.; Correia, S.; Ballester, A.; Vieitez, A. Non-zygotic embryogenesis in hardwood species. Crit. Rev. Plant Sci. 2019, 38, 29-97. [CrossRef]

120. Feher, A. Somatic embryogenesis-stress-induced remodeling of plant cell fate. Biochim. Biophys. Acta Gene Regul. Mech. 2015, 1849, 385-402. [CrossRef] [PubMed]

121. Chieng, L.M.; Chen, T.; Sim, S.; Goh, D.K. Induction of organogenesis and somatic embryogenesis of Gonystylus bancanus (Miq.) Kurz (Ramin) In Sarawak. Kuching Sarawak For. Corpor. ITTO 2014, 1, 1-28.

122. Corredoira, E.; Ballester, A.; Ibarra, M.; Vieitez, A. Induction of somatic embryogenesis in leaf and shoot apex explants from adult trees of the genus Eucalyptus. In Proceedings of the Third International Conference of the IUFRO unit 2.09. 02: Somatic Embryogenesis and Other Vegetative Propagation Technologies, Vitoria-Gasteiz, Spain, 18-12 September 2014; p. 66. 
123. Corredoira, E.; Ballester, A.; Ibarra, M.; Vieitez, A. Induction of somatic embryogenesis in explants of shoot cultures established from adult Eucalyptus globulus and E. salignaa $\times$ E. maidenii trees. Tree Physiol. 2015, 35, 678-690. [CrossRef]

124. Shirin, F.; Rana, P. In vitro plantlet regeneration from nodal explants of field-grown culms in Bambusa glaucescens Willd. Plant Biotechnol. Rep. 2007,1, 141-147. [CrossRef]

125. Kothari, S.; Agarwal, K.; Kumar, S. Inorganic nutrient manipulation for highly improved in vitro plant regeneration in finger millet- Eleusine coracana (L.) Gaertn. In Vitro Cell. Dev. Biol. Plant. 2004, 40, 515-519. [CrossRef]

126. Debergh, P.; Maene, L. A scheme for commercial propagation of ornamental plants by tissue culture. Sci. Hortic. 1981, 14, 335-345. [CrossRef]

127. Dibax, R.; Quisen, R.C.; Bona, C.; Quoirin, M. Plant regeneration from cotyledonary explants of Eucalyptus camaldulensis Dehn and histological study of organogenesis in vitro. Braz. Arch. Biol. Technol. 2010, 53, 311-318. [CrossRef]

128. Radmann, E.B.; Bianchi, V.J.; Souza, T.M.; Fachinello, J.C.; de Oliveria, R.P. Influencia da composiao do meio de cultivo e do tipo de explante na micropropagaation do porta-enxerto de Prunus sp. GXN-9. Sci. Agraria 2009, 10, 095-101. [CrossRef]

129. Oberschelp, G.P.J.; Goncalves, A.N. Assessing the effects of basal media on the in vitro propagation and nutritional status of Eucalyptus dunnii Maiden. In Vitro Cell. Dev. Biol. Plant. 2016, 52, 28-37. [CrossRef]

130. Brondani, G.E.; de Wit Ondas, H.W.; Baccarin, F.J.B.; Goncalves, A.N.; de Almeida, M. Micropropagation of Eucalyptus benthamii to form a clonal micro-garden. In Vitro Cell. Dev. Biol. Plant. 2012, 48, 478-487. [CrossRef]

131. Glocke, P.; Delaporte, K.; Collins, G.; Sedgley, M. Micropropagation of juvenile tissue of Eucalyptus erythronema $\times$ Eucalyptus stricklandii cv.'urrbrae gem'. In Vitro Cell. Dev. Biol. Plant. 2006, 42, 139-143. [CrossRef]

132. Lanoue, J.; Leonardos, E.D.; Grodzinski, B. Effects of light quality and intensity on diurnal patterns and rates of photo-assimilate translocation and transpiration in tomato leaves. Front. Plant Sci. 2018, 9, 756. [CrossRef]

133. Lima, L.; Seabra, A.; Melo, P.; Cullimore, J.; Carvalho, H. Post-translational regulation of cytosolic glutamine synthetase of Medicago truncatula. JExB 2006, 57, 2751-2761. [CrossRef]

134. Chen, J.; Ziv, M. The effect of ancymidol on hyperhydricity, regeneration, starch and antioxidant enzymatic activities in liquid-cultured Narcissus. Plant Cell Rep. 2001, 20, 22-27. [CrossRef]

135. Levin, R.; Alper, Y.; Stav, R.; Watad, A.A. Methods and apparatus for liquid media and semi-automated micropropagation. Acta Hortic. 1996, 447, 659-664. [CrossRef]

136. Ziv, M. The control of bioreactor environment for plant propagation in liquid culture. Acta Hortic. 1994, 393, 25-38. [CrossRef]

137. Ramage, C.M.; Williams, R.R. Mineral nutrition and plant morphogenesis. In Vitro Cell. Dev. Biol. Plant. 2002, 38, 116-124. [CrossRef]

138. Borges, S.R.; Xavier, A.; Oliveira, L.S.D.; Lopes, A.P.; Otoni, W.C. In vitro multiplication of hybrid clones of Eucalyptus globulus. Rev. Árvore 2011, 35, 173-182. [CrossRef]

139. Brondani, G.E.; Araujo, M.A.D.; Alcantara, B.K.D.; Carvalho, J.G.D.; Goncalves, A.N.; Almeida, M.d. In vitro organogenesis of Eucalyptus grandis: Effects of boron and calcium. Acta Sci. Agron. 2012, 34, $403-411$. [CrossRef]

140. Hannachi, S. Morphological, Ecophysiological and Biochemical Responses to Salt Stress in Eggplant (Solanum melongena L.); Ghent University: Ghent, Belgium, 2016.

141. Lanteri, M.L.; Pagnussat, G.C.; Lamattina, L. Calcium and calcium-dependent protein kinases are involved in nitric oxide-and auxin-induced adventitious root formation in cucumber. JExB 2006, 57, 1341-1351. [CrossRef] [PubMed]

142. Da Silva, A.L.L.; Tormen, G.C.R.; de Figueiredo, A.J.R.; dos Santos Ribeiro, A.L.; dos Santos, L.F.; Araujo, J.F.; Brondani, G.E. Carbohydrate sources, alanine and calcium for in vitro multiplication of Eucalyptus cloeziana $\mathrm{F}$. Muell. Iheringia. Ser. Botan. 2018, 73, 329-335.

143. Rasheed, M.K. Role of boron in plant growth: A review. J. Agric. Res. 2009, 47, 329-338.

144. Oberschelp, G.P.J. In Vitro Propagation of Eucalyptus Dunnii Maiden: Development of a New Basal Environment and Estimation of Genetic Parameters for Morphophysiological Characteristics; Escola Superior de Agricultura Luiz de Queiroz, Universidade de Saeo Paulo: Piracicaba, Brazil, 2014. 
145. Tanaka, M.; Fujiwara, T. Physiological roles and transport mechanisms of boron: Perspectives from plants. Pflugers Arch. 2008, 456, 671-677. [CrossRef] [PubMed]

146. Lin, H.; Jian, M.; Liang, L.; Pei, W.; Liu, X.; Zhang, H. Production of polyploids from cultured shoot tips of Eucalyptus globulus Labill by treatment with colchicine. Afr. J. Biotechnol. 2010, 9, 2252-2255.

147. Carvalho, D.C.D.; Silva, A.L.L.D.; Schuck, M.R.; Purcino, M.; Tanno, G.N.; Biasi, L.A. Fox grape cv. Bordo (Vitis labrusca L.) and grapevine cv. Chardonnay (Vitis vinifera L.) cultivated in vitro under different carbohydrates, amino acids and 6-Benzylaminopurine levels. Braz. Arch. Biol. Technol. 2013, 56, 191-201. [CrossRef]

148. Carvalho, D.; Biasi, L.; Telles, C. Organogeneie do caquizeiro 'Fuyu' from meristematic apps. Curr. Agric. Sci. Tech. 2004, 10, 3.

149. Rai, V. Role of amino acids in plant responses to stresses. Biol. Plant. 2002, 45, 481-487. [CrossRef]

150. George, E.F.; Hall, M.A.; De Klerk, G.J. The components of plant tissue culture media I: Macro-and micro-nutrients. In Plant Propagation by Tissue Culture; Springer: Berlin/Heidelberg, Germany, 2008; pp. 65-113.

151. Ramsundar, P.; Guldhe, A.; Singh, P.; Bux, F. Assessment of municipal wastewaters at various stages of treatment process as potential growth media for Chlorella sorokiniana under different modes of cultivation. Bioresour. Technol. 2017, 227, 82-92. [CrossRef]

152. Abiri, R.; Shaharuddin, N.A.; Maziah, M.; Yusof, Z.N.B.; Atabaki, N.; Sahebi, M.; Valdiani, A.; Kalhori, N.; Azizi, P.; Hanafi, M.M. Role of ethylene and the APETALA 2/ethylene response factor superfamily in rice under various abiotic and biotic stress conditions. Environ. Exp. Bot. 2017, 134, 33-44. [CrossRef]

153. Mukherjee, S.; Kutty, N.N.; Bera, P.; Mitra, A. Impact of light and sucrose supplementation on cellular differentiation, metabolic shift and modulation of gene expression in hairy roots of Daucus carota. Plant Cell Tissue Organ Cult. 2019, 136, 383-397. [CrossRef]

154. Jung Kwak, S.S.; Kim, S.W.; Lee, H.; Choi, C.; Liu, J.R. Improvement of the catharanthine productivity in hairy root cultures of Catharanthus roseus by using monosaccharides as a carbon source. Biotechnol. Lett. 1992, 14, 695-700. [CrossRef]

155. Verma, P.; Mathur, A.K. Agrobacterium tumefaciens-mediated transgenic plant production via direct shoot bud organogenesis from pre-plasmolyzed leaf explants of Catharanthus roseus. Biotechnol. Lett. 2011, 33, 1053-1060. [CrossRef] [PubMed]

156. Verma, P.; Sharma, A.; Khan, S.A.; Mathur, A.K.; Shanker, K. Morphogenetic and chemical stability of long-term maintained Agrobacterium-mediated transgenic Catharanthus roseus plants. Nat. Prod. Res. 2015, 29, 315-320. [CrossRef] [PubMed]

157. De Assis, T.F.; Fett-Neto, A.G.; Alfenas, A.C. Current techniques and prospects for the clonal propagation of hardwoods with emphasis on Eucalyptus. In Plantation Forest Biotechnology for the 21st Century; Research Signpost: Trivandrum, India, 2004; pp. 303-333.

158. Wang, C.; Fu, L.; Tong, X.; Yang, Q.; Zhang, W. Efficient and selective conversion of sucrose to 5-hydroxymethylfurfural promoted by ammonium halides under mild conditions. Carbohydr. Res. 2012, 347, 182-185. [CrossRef] [PubMed]

159. Van Reis, R.; Zydney, A. Bioprocess membrane technology. J. Membr. Sci. 2007, 297, 16-50. [CrossRef]

160. Hazarika, B. Morpho-physiological disorders in in vitro culture of plants. Sci. Hortic. 2006, 108, $105-120$. [CrossRef]

161. Dai, Z.W.; Meddar, M.; Renaud, C.; Merlin, I.; Hilbert, G.; Delrot, S.; Gomes, E. Long-term in vitro culture of grape berries and its application to assess the effects of sugar supply on anthocyanin accumulation. JExB 2013, 65, 4665-4677. [CrossRef]

162. El Far, M.; Taie, H.A. Antioxidant activities, total anthocyanins, phenolics and flavonoids contents of some sweetpotato genotypes under stress of different concentrations of sucrose and sorbitol. Aust. J. Basic Appl. Sci. 2009, 3, 3609-3616.

163. Jo, E.A.; Tewari, R.K.; Hahn, E.J.; Paek, K.Y. In vitro sucrose concentration affects growth and acclimatization of Alocasia amazonica plantlets. Plant Cell Tissue Organ Cult. 2009, 96, 307. [CrossRef]

164. Sircar, D.; Mukherjee, C.; Beuerle, T.; Beerhues, L.; Mitra, A. Characterization of p-hydroxybenzaldehyde dehydrogenase, the final enzyme of p-hydroxybenzoic acid biosynthesis in hairy roots of Daucus carota. Acta Physiol. Plant. 2011, 33, 2019-2024. [CrossRef] 
165. Welander, M.; Pawlicki, N. Carbon compounds and their influence on in vitro growth and organogenesis. In Physiology, Growth and Development of Plants in Culture; Springer: Berlin/Heidelberg, Germany, 1994; pp. 83-93.

166. Wotavova-Novotna, K.; Vejsadova, H.; Kindlmann, P. Effects of sugars and growth regulators on in vitro growth of Dactylorhiza species. Biol. Plantarum 2007, 51, 198-200. [CrossRef]

167. Klein, S.; Fiebig, A.; Noga, G.; Hunsche, M. Influence of light quality on leaf physiology of sweet pepper plants grown under drought. Theor. Exp. Plant Physiol. 2018, 30, 287-296. [CrossRef]

168. Craig, D.S. Determining Effective Ratios of Red and Far-Red Light from Light-Emitting Diodes that Control Flowering of Photoperiodic Ornamental Crops; Michigan State University: East Lansing, MI, USA, 2012.

169. Kumar, A.; Palni, L. The effect of light source and gelling agent on micropropagation of Rosa damascena Mill. and Rhynchostylis retusa (L.) Bl. J. Hortic. Sci. Biotechnol. 2003, 78, 786-792. [CrossRef]

170. Sutter, E.; Langhans, R. Formation of epicuticular wax and its effect on water loss in cabbage plants regenerated from shoot-tip culture. Can. J. Bot. 1982, 60, 2896-2902. [CrossRef]

171. Xia, J.; Li, Y.; Zou, D. Effects of salinity stress on PSII in Ulva lactuca as probed by chlorophyll fluorescence measurements. Aquat. Bot. 2004, 80, 129-137. [CrossRef]

172. Lin, C. Blue light receptors and signal transduction. Plant Cell 2002, 14, S207-S225. [CrossRef]

173. Hernandez-Sebastia, C.; Piche, Y.; Desjardins, Y. Water relations of whole strawberry plantlets in vitro inoculated with Glomus intraradices in a tripartite culture system. Plant Sci. 1999, 143, 81-91. [CrossRef]

174. Stoneman, G. Ecology and physiology of establishment of eucalypt seedlings from seed: A review. Aust. For. 1994, 57, 11-29. [CrossRef]

175. Gavira, M.; Roldan, M.D.; Castillo, F.; Moreno-Viviian, C. Regulation of NAP gene expression and periplasmic nitrate reductase activity in the phototrophic bacterium Rhodobacter sphaeroides DSM158. J. Bacteriol. 2002, 184, 1693-1702. [CrossRef] [PubMed]

176. Sharma, A.K.; Raghuram, N.; Chandok, M.R.; Das, R.; Sopory, S.K. Investigations on the nature of the phytochrome-induced transmitter for the regulation of nitrate reductase in etiolated leaves of maize. JExB 1994, 45, 485-490. [CrossRef]

177. Appenroth, K.J.; Meco, R.; Jourdan, V.; Lillo, C. Phytochrome and post-translational regulation of nitrate reductase in higher plants. Plant Sci. 2000, 159, 51-56. [CrossRef]

178. Jeon, M.W.; Ali, M.B.; Hahn, E.J.; Paek, K.Y. Effects of photon flux density on the morphology, photosynthesis and growth of a CAM orchid, Doritaenopsis during post-micropropagation acclimatization. Plant Growth Regul. 2005, 45, 139-147. [CrossRef]

179. Raffo, A.; Mozzanini, E.; Nicoli, S.F.; Lupotto, E.; Cervelli, C. Effect of light intensity and water availability on plant growth, essential oil production and composition in Rosmarinus officinalis L. ur. Food Res. Technol. 2020, 246, 167-177. [CrossRef]

180. Shen, G.; Tan, S.; Sun, X.; Chen, Y.; Li, B. Experimental Evidence for the Importance of Light on Understory Grass Communities in a Subtropical Forest. Front. Plant Sci. 2020, 11, 11-18. [CrossRef]

181. Le Roux, J.J.; Van Staden, J. Micropropagation and tissue culture of Eucalyptus-A review. Tree Physiol. 1991, 9, 435-477. [CrossRef]

182. De Fossard, R.A.; Bennett, M.T.; Gorst, J.R.; Bourne, R.A. Tissue culture propagation of Eucalyptus ficifolia F. Muell. International plant propagators' society: Combined proceedings. Int. Plant Propag. Soc. 1987, $28,427-435$.

183. Ma, C.; Deepika, R.; Myburg, A.A.; Ranik, M.; Strauss, S.H. Development of Eucalyptus tissue culture conditions for improved in vitro plant health and transformability. BMC Proc. 2011, 5, 1-3. [CrossRef]

184. Palhares, G.A.; Sánchez, R.R.; Ruiz, M.C.; Trina, D.P.; García, Y.G.; González-Olmedo, J.L. Effects of photomixotrophic conditions on plants of Eucalyptus urograndis propagated in temporary immersion bioreactors. Int. J. Environ. 2018, 3, 558-566. [CrossRef]

185. Miranda, N.A.; Xavier, A.; Otoni, W.C.; Gallo, R.; Gatti, K.C.; de Moura, L.C.; Santos, S.S.D.O. Quality and intensity of light in the in vitro development of microstumps of Eucalyptus urophylla in a photoautotrophic system. For. Sci. 2020, 66, 1-7. [CrossRef]

186. Mankessi, F.; Saya, A.; Baptiste, C.; Nourissier, S.; Monteuuis, O. In vitro rooting of genetically related Eucalyptus urophylla Eucalyptus grandis clones in relation to the time spent in culture. Trees 2009, 23, 931-940. [CrossRef] 
187. Moubayidin, L.; Di Mambro, R.; Sabatini, S. Cytokinin-auxin crosstalk. Trends Plant Sci. 2009, 14, $557-562$. [CrossRef] [PubMed]

188. Fei, L. Towards Automating Micropropagation: From Cells to Shoots to Plants in One Step. Ph.D. Thesis, Worcester Polytechnic Institute, Worcester, MA, USA, April 2015.

189. Fett-Neto, A.G.; Fett, J.P.; Goulart, L.W.V.; Pasquali, G.; Termignoni, R.R.; Ferreira, A.G. Distinct effects of auxin and light on adventitious root development in Eucalyptus saligna and Eucalyptus globulus. Tree Physiol. 2001, 21, 457-464. [CrossRef] [PubMed]

190. Da Rocha Correela, L.; Paim, D.C.; Schwambach, J.; Fett-Neto, A.G. Carbohydrates as regulatory factors on the rooting of Eucalyptus saligna Smith and Eucalyptus globulus Labill. Plant Growth Regul. 2005, 45, 63-73.

191. Tournier, V.; Grat, S.; Marque, C.; El Kayal, W.; Penchel, R.; de Andrade, G.; Boudet, A.M.; Teulieres, C. An efficient procedure to stably introduce genes into an economically important pulp tree (Eucalyptus grandis $\times$ Eucalyptus urophylla). Transgenic Res. 2003, 12, 403-411. [CrossRef] [PubMed]

192. Ahad, A.; John, E.; Maqbool, A.; Malik, K.A. Development of efficient micropropagation system for E. camaldulensis with respect to age of explants. Pak. J. Agric. Sci. 2018, 55, 23-27.

193. Bandyopadhyay, S.; Hamill, J.D. Ultrastructural studies of somatic embryos of Eucalyptus nitens and comparisons with zygotic embryos found in mature seeds. Ann. Bot. 2000, 86, 237-244. [CrossRef]

194. Herve, P.; Jauneau, A.; Paqques, M.; Marien, J.N.; Boudet, A.M.; Teuliires, C. A procedure for shoot organogenesis in vitro from leaves and nodes of an elite Eucalyptus gunnii clone: Comparative histology. Plant Sci. 2001, 161, 645-653. [CrossRef]

195. Gonzaez, E.R.; de Andrade, A.; Bertolo, A.L.; Lacerda, G.C.; Carneiro, R.T.; Defavari, V.A.P.; Labate, M.T.V.; Labate, C.A. Production of transgenic Eucalyptus grandis $x$ E. urophylla using the sonication-assisted Agrobacterium transformation (SAAT) system. Funct. Plant Biol. 2002, 29, 97-102. [CrossRef]

196. Girijashankar, V. Genetic transformation of Eucalyptus. Physiol. Mol. Biol. Plants 2011, 17, 9-23. [CrossRef] [PubMed]

197. Prakash, M.; Gurumurthi, K. Genetic transformation and regeneration of transgenic plants from precultured cotyledon and hypocotyl explants of Eucalyptus tereticornis Sm. using Agrobacterium tumefaciens.. In Vitro Cell. Dev. Biol. 2009, 45, 429-434. [CrossRef]

198. Trindade, M.H.M. Eucalyptus Globulus Labill: Systems for In Vitro Regeneration. Ph.D. Thesis, University of Lisbon, Lisboa, Portugal, 1996.

199. Muralidharan, E.; Mascarenhas, A. Somatic embryogenesis in Eucalyptus. In Somatic Embryogenesis in Woody Plants; Springer: Berlin/Heidelberg, Germany, 1995; pp. 23-40.

200. Watt, M.; Blakeway, F.; Termignoni, R.; Jain, S. (Eds.) Somatic Embryogenesis in Eucalyptus Grandis and E. dunni. Somatic Embryogenesis in Woody Plants; Springer: Berlin/Heidelberg, Germany, 1999; pp. 63-78.

201. Termignoni, R.R.; Wang, P.J.; Hu, C.Y. Somatic embryo induction in Eucalyptus dunnii. Plant Cell Tissue Organ Cult. 1996, 45, 129-132. [CrossRef]

202. Kaeppler, S.M.; Kaeppler, H.F.; Rhee, Y. Epigenetic aspects of somaclonal variation in plants. In Plant Gene Silencing; Springer: Berlin/Heidelberg, Germany, 2000; pp. 59-68.

203. Gamborg, O.L.C.; Miller, R.A.; Ojima, K. Nutrient requirements of suspension cultures of soybean root cells. Exp. Cell Res. 1968, 50, 151-158. [CrossRef]

204. Ho, C.K.; Chang, S.H.; Tsay, J.Y.; Tsai, C.J.; Chiang, V.; Chen, Z.Z. Agrobacterium tumefaciens-mediated transformation of Eucalyptus camaldulensis and production of transgenic plants. Plant Cell Rep. 1998, 17, 675-680. [CrossRef]

205. Ito, K.; Doi, K.; Tatemichi, Y.; Shibata, M. Plant regeneration of Eucalypts from rotating nodule cultures. Plant Cell Rep. 1996, 16, 42-45. [CrossRef]

206. Alves, E.C.S.D.C.; Xavier, A.; Otoni, W.C. Organogenesis of the leaf explant of Eucalyptus grandis x E. urophylla clones. Pesq. Agropec. Bras. 2004, 39, 421-430. [CrossRef]

207. Takemori, N.; Marschner, R.; Quoirin, M.; Bona, C.; Zanette, F. Anatomical study of Racosperma (ex-Acacia) mangium tissues cultured in vitro. Braz. Arch. Biol. Technol. 2000, 43, 1-10. [CrossRef] 
208. Stipp, L.C.L.; Mendes, B.M.J.; Piedade, S.M.S.; Rodriguez, A.P.M. In vitro morphogenesis of Cucumis melo var. inodorus. Plant Cell Tissue Organ Cult. 2001, 65, 81-89. [CrossRef]

Publisher's Note: MDPI stays neutral with regard to jurisdictional claims in published maps and institutional affiliations.

(C) 2020 by the authors. Licensee MDPI, Basel, Switzerland. This article is an open access article distributed under the terms and conditions of the Creative Commons Attribution (CC BY) license (http://creativecommons.org/licenses/by/4.0/). 